\title{
Cell Therapy for Parkinson's Disease: Status and Perspectives
}

\author{
Pia Jensen, Christina Krabbe and Morten Meyer \\ Department of Neurobiology Research, Institute of Molecular Medicine, \\ University of Southern Denmark, Odense C \\ Denmark
}

\section{Introduction}

Idiopathic Parkinson's disease (PD) is caused by progressive degeneration of melanin containing dopaminergic neurons in substantia nigra pars compacta in the upper brain stem. The loss of dopaminergic neurons results in a gradual decrease of dopaminergic input to the striatum leading to the cardinal symptoms rigidity, tremor, hypokinesia and occasionally postural instability.

One of the prospects for a curative treatment for PD is to replace the lost dopaminergic neurons by intracerebral transplantation. Grafting of fetal midbrain dopaminergic neurons into the dopamine-depleted striatum has thus emerged as an experimental therapeutic approach for PD. Preclinical and clinical trials have demonstrated that such fetal dopaminergic neurons have the potential to markedly improve motor function in animal models and PD patients. Over the last decades, approximately 400 PD patients have been grafted, and graft survival in the dopamine-depleted striatum, with substantial motor improvements, has been reported particularly in younger patients. However, looking across all the studies, where several different protocols and donor ages have been used, the symptomatic relief is inconsistent and not yet of a magnitude that would justify treatment at a large scale. Ethical concerns related to the use of human fetal brain tissue, shortage of suitable donor tissue and a poor survival of grafted dopaminergic neurons has stimulated the search for other reliable sources of donor material and development of applicable gene technological techniques for improving graft survival, differentiation and functional integration.

Expanded midbrain precursor cells, predifferentiated human embryonic stem cells or induced pluripotent stem cells as well as human neural stem cells and mesenchymal stem cells have been proposed as promising alternative sources of donor cells. In this chapter we will review current status and discuss crucial issues that remain to be resolved to develop cell replacement into an effective and safe therapy.

\section{Treatment strategies for Parkinson's disease}

Conventional treatment of PD is symptomatic and includes pharmacotherapy, possibly combined with surgical deep brain stimulation (DBS). These symptomatic treatments are highly effective at managing the motor symptoms, especially in the early stages of the 
disease. However, they have limited capability to improve symptoms at more advanced stages, thus new therapeutic and restorative strategies, including the use of neuroprotective agents, in vivo gene therapy, genetically engineered cell lines ("cell factories") and stem cells, are in development. Providing a continuous supply of dopamine to the striatum using viral delivery of enzymes in the dopamine synthesis is one approach. Other experimental strategies aim at protecting and stimulating sprouting of remaining dopaminergic neurons using neurotrophic factors or directly replacing lost innervation by transplantation of primary dopaminergic tissue or stem cell-derived dopaminergic neurons. Here we focus on the perspectives of recent developments in the latter approach and provide a historical review of neural transplantation as potential future therapy for PD.

\subsection{Symptomatic treatment strategies}

The observation of dopamine depletion in the striatum of PD patients (Carlsson, Lindqvist, and Magnusson 1957), led to development of the now classical L-dopa replacement therapy, with subsequent dramatic clinical benefit to virtually all patients. Medication with the dopamine precursor L-dopa results in effective improvements of motor symptoms, and it is still the most commonly used drug for treatment of PD - alone or in combination with other drugs acting primarily on the dopaminergic system. Unfortunately, L-dopa gradually loses its effect (typically after 5-7 years of L-dopa treatment) as the remaining dopaminergic neurons continue to degenerate and patients experience end-of-dose deterioration and start to fluctuate between states, where they are immobile called "off"-periods" and states where they are able to move called "on"-periods". In addition, the treatment is coupled to further motor complications such as L-dopa-induced dyskinesias and often also psychiatric symptoms (Fahn 2006). This clearly underlines the need for development of new systemic pharmacological therapies or alternative treatment strategies.

In addition to L-dopa treatment, other drugs are used to stimulate the deteriorated dopaminergic neurotransmission, such as dopamine agonists and inhibitors of monoamine oxidase $\mathrm{B}$ and catechol-O-methyl transferase, both enzymes which prevent the breakdown of dopamine (Hauser and Zesiewicz 2007). So far, no medication has been shown to slow the loss of dopaminergic neurons in PD, but there are some indications from preclinical studies that the monoamine oxidase $B$ inhibitor, rasagiline, might have neuroprotective effects. Recently, a large, double-blind placebo-controlled clinical trial showed that patients receiving a rasagiline dose of $1 \mathrm{mg}$ per day experienced benefits that were consistent with a possible disease modifying effect, whereas treatment with a dose of $2 \mathrm{mg}$ per day had no such effect (Olanow et al. 2009). Thus, these results must be further evaluated and additional studies performed in order to draw valid conclusions. A problem in studies of neuroprotection by medicaments known for symptomatic relief is the use of clinical measures, such as a change in score on the Unified Parkinson's Disease Rating Scale (UPDRS), as primary outcome measures. This makes it difficult to distinguish pure symptomatic benefit from real neuroprotection, as both would be reflected in improved scores. Thus, the possibilities of using independent and objective biomarkers in future trials, such as Positron Emmision Tomography (PET) imaging of nigrostriatal dopamine terminals are being investigated (Lohle and Reichmann 2010).

Surgical procedures, such as thalamotomy or pallidotomy, and circuit inhibition by highfrequency DBS through electrodes implanted in the globus pallidus or the subthalamic nucleus have gained considerably attention as therapies for PD. In general, DBS is preferable to the prior ablative surgical methods since electrical stimulation is both reversible and 
programmable. Especially, stimulation in the subthalamic nucleus has shown to improve motor function and reduce dyskinesias and need for medication (Pahwa et al. 2006). Although ablative surgery and DBS eliminate or ameliorate certain symptoms of the disease, the long-term effect is not well known. DBS has been increasingly established in several clinical trials, but questions remain regarding the best timing of the procedure, the best anatomical target for stimulation, ways to avoid preoperative and postoperative adverse effects as well as which patients should be selected for the treatment (Morley and Hurtig 2010). Unfortunately, this treatment is also not restorative and cannot slow down or prevent disease progression, and most patients experience progressive worsening over time. Furthermore, DBS only treat a fairly specific set of symptoms (mostly, L-dopa induced dyskinesias and/or tremor) and has no effect on other clinical manifestations, such as postural instability.

\subsection{Intracerebral transplantation - a historical perspective}

Cell replacement therapy for treatment of $\mathrm{PD}$ is based on the idea that immature dopaminergic neurons, following transplantation and functional integration, can restore dopaminergic neurotransmission and exert long-lasting effects on motor symptoms. Based on data from animal experimentation, the current main focus is on elevating striatal dopamine levels rather than trying to reconstruct the relatively long nigrostriatal pathway.

Here we provide an overview of different cell types and tissues that have been used for grafting in PD - with emphasis on fetal ventral mesencephalic tissue, which has resulted in the greatest clinical benefits. This is followed by a discussion of future perspectives of cell replacement for $\mathrm{PD}$, with particular focus on stem cell based strategies.

\subsubsection{Autografts}

Ethical and immunological issues can be avoided by use of autografts for treatment of any disorder, including PD, making this strategy very attractive. The first clinical experiments with grafting to the brains of PD patients involved autografts of adrenal medullary tissue, which secretes dopamine among other catecholamines (Backlund et al. 1985; Lindvall et al. 1987; Drucker-Colin et al. 1988; Freed, Poltorak, and Becker 1990). These small open-label clinical trials caused initial enthusiasm, but have largely been abandoned since 1989 after failure in a number of clinical trials (Allen et al. 1989; Goetz et al. 1991). Some patients experienced modest effects for a limited period of time, and post-mortem studies showed poor survival of the grafted tissue (Hurtig et al. 1989; Kordower et al. 1991). A recent followup study, performed 16 years after adrenal medulla transplantation showed few surviving chromaffin cells and a complete absence of tyrosine hydroxylase (TH)-positive cells at the graft site, providing evidence of no long-term survival of adrenal medullary transplants (Kompoliti et al. 2007).

Autografts of sympathetic ganglion neurons, collected from the cervical or thoracic sympathetic chain, have also been considered as a source of donor cells for PD patients. Sympathetic ganglion neurons have been shown to express the enzymes aromatic amino acid decarboxylase and vesicular monoamine transporter 2, which are involved in production and transport of dopamine, both in vitro and after transplantation to a rat model of PD (Nakao et al. 2001; Nakao et al. 2004). Thus, their ability to convert exogenous L-dopa to dopamine and to store the synthesized dopamine was thought to be a potential action. Accordingly, some patients experienced increased duration of L-dopa-induced "on"-periods 
with consequent reduction of time spent in "off" phase with overall improvement in bradykinesia, but no significant change in the UPDRS scores (Itakura et al. 1997; Nakao et al. 2004). Overall, these limited clinical benefits along with the rather invasive techniques for obtaining the ganglionic tissue make this an unsuitable approach.

A third approach has been autografts of carotid body cells, which normally secrete dopamine and divide in response to hypoxic stimuli (Espejo et al. 1998). Striatal transplantation of carotid body cells resulted in partial functional recovery in rat and primate models of PD (Espejo et al. 1998; Luquin et al. 1999). This led to a small clinical study (Arjona et al. 2003), where most patients experienced motor improvement seen as a reduction in their UPDRS "off"-score, however, there was no increase in [18$\left.{ }^{18} \mathrm{~F}\right]$-fluorodopa uptake in the transplanted striatum as seen by PET imaging. Furthermore, it was shown that the surviving number of dopaminergic neurons in the transplants was very low (Arjona et al. 2003). Thus, the reason for the motor improvements remains unclear.

\subsubsection{Fetal ventral mesencephalic grafts}

In 1979, the first two successful attempts of transplantation with fetal ventral mesencephalic cells in animal models were reported (Perlow et al. 1979; Bjorklund and Stenevi 1979). These studies showed that rat fetal ventral mesencephalic tissue transplanted into rats with unilateral 6-hydroxydopamine (6-OHDA) lesions could reverse lesion-induced behavioral deficits. Furthermore, the grafted dopaminergic neurons innervated the striatum and were found to form synapses with host neurons. These initial and pioneering results initiated a series of studies in rodents examining the survival and functional capacity of dopaminergic neurons following grafting into different brain regions (Dunnett et al. 1983; Dunnett et al. 1981; Freund et al. 1985). Improvements were clearly seen when grafts were placed in the striatum, whereas attempts to graft into the substantia nigra, the ventral mesencephalic subregion with dopaminergic cell body degeneration, showed survival of cells, but they did not innervate the striatum and had no significant functional effects (Dunnett et al. 1983). In 1986, human fetal ventral mesencephalic tissue was reported to survive transplantation into immunosuppressed, 6-OHDA lesioned rats and exert functional effects on motor behavior (Brundin et al. 1986; Stromberg et al. 1986). The best outcomes were seen for tissue derived from human fetuses, obtained at 5.5-8 weeks postconception. The results of these studies paved the way for the first systematic clinical transplantation trials with dopaminergic neurons to PD patients.

Since 1987, several so-called open-label trials (trials where small groups of patients receive transplants without the use of any control group or blinding procedure) have been performed. These initial trials have revealed that fetal human nigral neurons, taken at a stage of development when they have started to express their dopaminergic phenotype, can survive, integrate and function in the human brain. In 1990, the first study demonstrating survival and functional effects of grafted human ventral mesencephalic tissue in an immunosuppressed PD patient was published (Lindvall et al. 1990) and during the following years a wide number of open-label trials reported improved motor functions in the absence of medication and reduced time spend in the "off" phase (Madrazo et al. 1990; Brundin et al. 2000; Freed et al. 1992; Freed, Breeze, Rosenberg, Schneck, Wells, Barrett, Grafton, Huang et al. 1990; Freed, Breeze, Rosenberg, Schneck, Wells, Barrett, Grafton, Mazziotta et al. 1990; Lindvall et al. 1989; Lindvall et al. 1994; Peschanski et al. 1994). Furthermore, in some cases even reduced dyskinesias in the "on" state were seen (Freed, Breeze, Rosenberg, Schneck, Wells, Barrett, Grafton, Huang et al. 1990; Freed, Breeze, 
Rosenberg, Schneck, Wells, Barrett, Grafton, Mazziotta et al. 1990; Madrazo et al. 1990) and some patients were able to stop their antiparkinsonian medication. Imaging studies showed that the grafts gradually gave rise to improved striatal $\left[{ }^{18} \mathrm{~F}\right]$-fluorodopa uptake and few patients, who died of unrelated courses long time after surgery, had several thousand surviving dopaminergic neurons that innervated their striatum (Mendez et al. 2005; Kordower et al. 1995).

A major problem with transplantation of mesencephalic dopaminergic neurons in PD is that the outcome has varied dramatically between transplantation centers and also between patients treated at the same center essentially using the same procedure. Two main parameters are likely to be responsible for the mixed outcomes. First, differences between the PD patients regarding age, genetic background, stage of their disease, prior medication and precise neuropathological profile. The second issue is related to the surgery and postgrafting treatment such as numbers of cells being grafted, number and sites of injection, variation in surgical technique as well as tissue preparation (fresh versus stored tissue) and immunosuppression treatment (Bjorklund et al. 2003).

\subsubsection{Double-blind placebo-controlled trials}

The greatest setback for the neural transplantation field in PD was the outcome of two double-blind placebo-controlled trials in the late 1990s (Olanow et al. 2003; Freed et al. 2001). The objective of these trials, funded by the National Institute of Health (USA), was to properly support the clinical benefits of the transplantation procedure seen in the open label trials. The first trial involved 40 PD patients between 34 and 75 years of age and with average disease duration of 14 years (Freed et al. 2001). Patients were randomly assigned to receive a transplant or undergo sham surgery. The human ventral mesencephalic donor tissue, obtained from 7-8 week old fetuses, was cultured for up to 4 weeks as "tissue strands". Cultured tissue from two embryos was transplanted into the putamen on each side and no immunosuppression was used. Control patients received a sham-surgery with burr holes, but without penetration of the meninges. One year after transplantation there was no significant improvement in the transplant group $(20 \%$ reduction in the motor part of the UPDRS as compared to the placebo group). However, when looking at the subgroup of younger patients (<60 years) a significant reduction of $30-35 \%$ was found. Though, subsequent analysis have suggested that the main determinant of this correlation was the preoperative L-dopa responsiveness rather than the age of the patient, as even older patients with good preoperative L-dopa responsiveness showed similar improvements (Bjorklund et al. 2003). Although the clinical benefits were modest and variable, PET scannings showed significant increase in $\left.{ }^{18} \mathrm{~F}\right]$-fluorodopa uptake in the putamen of the transplant as compared to the placebo group, and postmortem analysis showed dopaminergic neuronal survival and fiber outgrowth in the graft. However, the number of surviving dopaminergic neurons was lower than that reported for other patients with good clinical response to their transplants (Freed et al. 2001).

Another outcome and concern from this trial was the appearance of L-dopa-independent, graft-induced dyskinesias in $15 \%$ of the patients more than 1 year after surgery. The reasons for the limited clinical outcome and the induction of graft-induced dyskinesias remain largely unknown, but various factors have been suggested to be of critical relevance. For instance, the amount of grafted tissue was smaller than that of other more successful trials, which may explain the low recovery of dopaminergic neurons seen by postmortem analysis. Furthermore, the absence of immunosuppressive treatment may have compromised 
dopaminergic cell survival, as may the storage of the fetal tissue up to 4 weeks prior to transplantation.

The second double-blind placebo-controlled trial involved 34 patients with advanced PD, aged between 30 and 75 years (Olanow et al. 2003). Patients were randomly assigned to receive bilateral transplantation with either 1 or 4 donors per side or sham surgery. Solid ventral mesencephalic tissue was obtained from 6-9 week old fetuses and stored for 2 days prior to transplantation. All patients received immunosuppression (cyclosporine A) starting 2 weeks before the transplantation and continuing for up to 6 month after surgery. Two years after transplantation, no significant treatment effects were assessed by the motor component of the UPDRS in the "off" medication, but there was a tendency for an improved motor score for the 4-donor group. Moreover, no differences between groups in terms of the change in time spend in "on" without dyskinesias and in required L-dopa dose was found. However, subsequent analysis based on disease severity showed that patients in the 4-donor group with preoperative less severe disease did display significant improvements in their UPDRS motor scores. Also patients both in the 1 and 4-donor groups showed significant motor improvements compared to placebo at 6 and 9 month after transplantation, but this effect declined thereafter, which may be related to the withdrawal of the immunosuppressive therapy at this time point. In fact, the initial improvements were similar to that reported for some of the previous open label trials. PET scannings showed significant bilateral increase in striatal $\left[{ }^{18} \mathrm{~F}\right]$-fluorodopa uptake in both transplant groups as compared to the placebo group, with the 4-donor group displaying the greatest increase. Postmortem analysis also revealed good survival of dopaminergic neurons with relatively good innervations of the striatum, again with the 4-donor group showing the best results. However, as in the study by Freed et al. (2001), development of significant off-medication graft-induced dyskinesias were observed in $56 \%$ of the grafted patients 6 to 12 month after transplantation.

Thus, the results of these two double-blind placebo-controlled trials raised serious concerns about the utility and safety of fetal ventral mesencephalic transplants in PD patients. The main concerns related to the moderate efficacy of the transplants compared to previous open-label trials and to the development of graft-induced dyskinesias in a significant number of patients. The differences in the study design between the open-label trials and the placebo-controlled trials may contribute the the poor outcome of the placebo-controlled studies. However, the specific reasons remain largely unresolved as further discussed in the next section.

\subsubsection{Lessons from the clinical trials and the TRANSEURO project}

Several issues have been suggested as explanations for the inconsistencies of the transplantation trials using fetal ventral mesencephalic tissue, such as patient selection, tissue preparation, graft placement and the need for immunosuppressive treatment. So far there is no clear consensus as to whether one or all of these factors contribute. As a consequence of all these possible confounders a re-evaluation of the field of neural grafting for PD has been undertaken. First, the indications that patient selection may be an important factor come from the observations that the best results in the double-blind placebocontrolled trials were seen for patients with less severe disease and good preoperative response to L-dopa. Furthermore, there is also some evidence that older patients generally do less well (Winkler, Kirik, and Bjorklund 2005). Second, parameters such as the number and age of donor fetuses, surgical techniques applied and graft placement may all have 
affected the survival and functional integration of the grafted dopaminergic neurons. In the study by Freed et al. (2001) the method involved less tissue, stored for longer times, while the Olanow et al. (2003) study used tissue pieces, stored for a short period of time. Several studies have shown that a variety of issues in the preparation process are critical for the optimization of dopaminergic cell survival in the transplants and some of the factors used in the protocols from these trials may have had harmful effects on dopaminergic cell survival after transplantation. Third, immunosuppression is an issue. Even though the brain is considered an immunologically privileged site, the host immunesystem can respond to the graft. Previous animal experiments have shown that intracerebral allografts of fetal ventral mesencephalic tissue can survive for prolonged periods in the absence of any immunosuppression (Head and Griffin 1985). However, in cases where the donor and host differ immunologically on both major and minor histocompatibility antigens, the graft is likely to induce a long-lasting inflammatory response, accompanied by upregulation of class I and class II antigens on the grafted cells, sustained expression of immunological markers, and macrophage and microglial activation at the graft site (Hudson et al. 1994; Shinoda et al. 1995, 1996). The intensity of the immune reaction can increase over time, indicating that the immune cells observed in the brain after grafting are not stationary and inactive but rather provide an ongoing inflammatory process (Shinoda et al. 1995). Nonetheless, the major clinical transplantation centers have in some cases chosen not to immunosuppres the PD patients (Freed et al. 2001) or to use a mild treatment for only 6 month (Olanow et al. 2003). Lastly, the mechanisms behind the development of graft-induced dyskinesias are not fully understood. These dyskinesias differ in nature compared to the typical L-dopa-induced dyskinesias. The severity tend to correlate negatively with the $\left[{ }^{18} \mathrm{~F}\right]$-fluorodopa uptake in the striatum prior to transplantation, but it does not correlate with improvement in the UPDSC scores or daily medication needs after transplantation. Moreover, their appearance does not seem to relate to the severity of the preoperative L-dopa induced dyskinesias or the change in these after transplantation. Several factors have been suggested to cause the graft induced dyskinesias, such as inhomogeneous dopaminergic reinnervation of the host putamen (Ma et al. 2002), the presence of cells other than A9 dopaminergic neurons within the grafts, especially serotonergic neurons included in the grafts (Carlsson et al. 2007; Carta et al. 2007) and the graft size and placement in the striatum (Lane et al. 2006).

Thus, increased understanding of possible mechanism behind the disappointing results of the two double-blind placebo-controlled trials has led to initiation of a new clinical trial using fetal transplants for PD. This exciting project, called TRANSEURO, is funded by the 7th Framework Program of the European Commission and is a major collaboration between leading experts as clinicians, scientists, industrial partners, ethicists and patients' representative in this field (http://www.transeuro.org.uk/index.html). The main goals of the project are to show that consistency and efficacy of dopaminergic cell replacement in PD can be improved by careful attention to tissue preparation and delivery, patient selection and immunosuppressive treatment as discussed above. Moreover, to show that dopaminergic cell replacement can be clinically efficacious in the absence of any troublesome graft induced dyskinesias in patients with mild PD and to develop a protocol that can serve as a template for all future clinical trials in the cell therapy field, including expected future stem cell-based therapies. The first patients are to be transplanted in the beginning of 2012. After that, a double-blind placebo-controlled trial will be performed at several centers in Europe and USA. The general idea is to try to push the field ahead, while techniques for development of suitable cells from human stem cells are being conducted (Holden 2009). 


\subsubsection{Long-term post-mortem studies of fetal mesencephalic grafts}

Recent post-mortem studies have shown that grafted dopaminergic neurons survive for up to 16 years in the brains of PD patients after transplantation (Mendez et al. 2008; Li et al. 2008; Kordower et al. 2008). These studies include in total 6 patients with long-term survival (9-16 years) after transplantation and all had experienced clinical benefits, though to a variable degree. In general, the grafts contained numerous TH-positive dopaminergic neurons with fibers innervating the host striatum. The grafts largely resembled those in patients who died 1.5-4 years after transplantation (Mendez et al. 2005; Kordower et al. 1996), though with lower numbers of TH-positive cells. Thus, these studies provide the first evidence of long-term survival of grafted dopaminergic neurons in PD. However, in two of these studies Lewy bodies and $\alpha$-synuclein aggregates were found in few of the grafted cells (Kordower et al. 2008; Li et al. 2008). Low levels of dopamine transporter was also found in some of the grafted cells, which had not been seen for patients who died 1.5 year after transplantation (Kordower et al. 2008). Thus, these observations suggest that the pathogenetic process in PD can affect the transplanted neurons. At the moment, it is unclear what the functional significance of these findings is, but it is important to note that the majority of the grafted cells appeared normal and healthy and even if the graft may start to degenerate after 10 years or more due to host to graft disease propagation, the therapeutic window for cell transplantation would still be wide enough to allow a significant clinical intervention.

\subsubsection{Xenografts}

Xenografting is transplantation of tissue between different species. Fetal porcine neural tissue has been considered the most suitable alternative source for transplantation into the human brain due to the ease of breeding and the similarity in brain size combined with a protracted gestational period, which may provide the basis for long-distance axonal growth after grafting. Another interesting perspective has been the potential development of nonimmunogenic transgenic donor pigs. The ability of xenografted ventral mesencephalic tissue to survive and mediate functional benefits in animal models of PD (Brevig et al. 2001; Galpern et al. 1996; Huffaker et al. 1989) led to a clinical safety trial, where 12 PD patients received unilateral striatal transplants of porcine ventral mesencephalic tissue suspensions (Schumacher et al. 2000; Deacon et al. 1997). A significant reduction in UPDRS was reported for some patients, but there was no increase in $\left[{ }^{18} \mathrm{~F}\right]$-fluorodopa uptake at the transplant site, and a postmortem study of a patient who died of unrelated causes 8 month after transplantation showed that only around $650 \mathrm{TH}$-positive neurons out of 12 million transplanted cells had survived. This finding suggests a lack of trophic support of the grafted tissue. Furthermore, some lymphocyte infiltration into and around the graft was found even though the patient was immunosupressed with cyclosporine A (Deacon et al. 1997). A second double-blind placebo controlled trial involving 18 patients caused only moderate improvements in UPDRS scores in both transplant and sham surgery groups. However, these results have only been published in a press release in March 2001 (Wijeyekoon and Barker 2009).

Due to these disappointing results the clinical use of this approach is considered doubtful, especially as the use of xenogenic tissue deals with some additional issues as compared to allogenic grafts. First, there are the problems of increased graft rejection and second, there is the risk of spreading infection across the species barrier by porcine endogenous retroviruses 
(Sayles, Jain, and Barker 2004). Thus, further work will be required to decide if fetal porcine tissue is of clinical relevance.

\section{Stem cells}

Stem cells are defined as undifferentiated cells without mature, tissue-specific characteristics that are able to reproduce themselves by division into identical daughter cells. Moreover, in response to proper stimuli stem cells are able to produce more specific progenitor cells that can further differentiate into one or more functional cell types. Stem cells are considered to represent a very promising source of cells cell replacement therapy in a number of diseases, including PD, due to these key properties, namely, self-renewal and multipotentiality as well as the possibility to manipulate these cells in vitro.

Dopaminergic neurons can be generated from stem cells of different sources (Fig. 1). Embryonic stem cells (ESCs) are isolated from the inner cell mass of the preimplantation blastocyst, and they have unlimited self-renewal capacity and are pluripotent, since they are

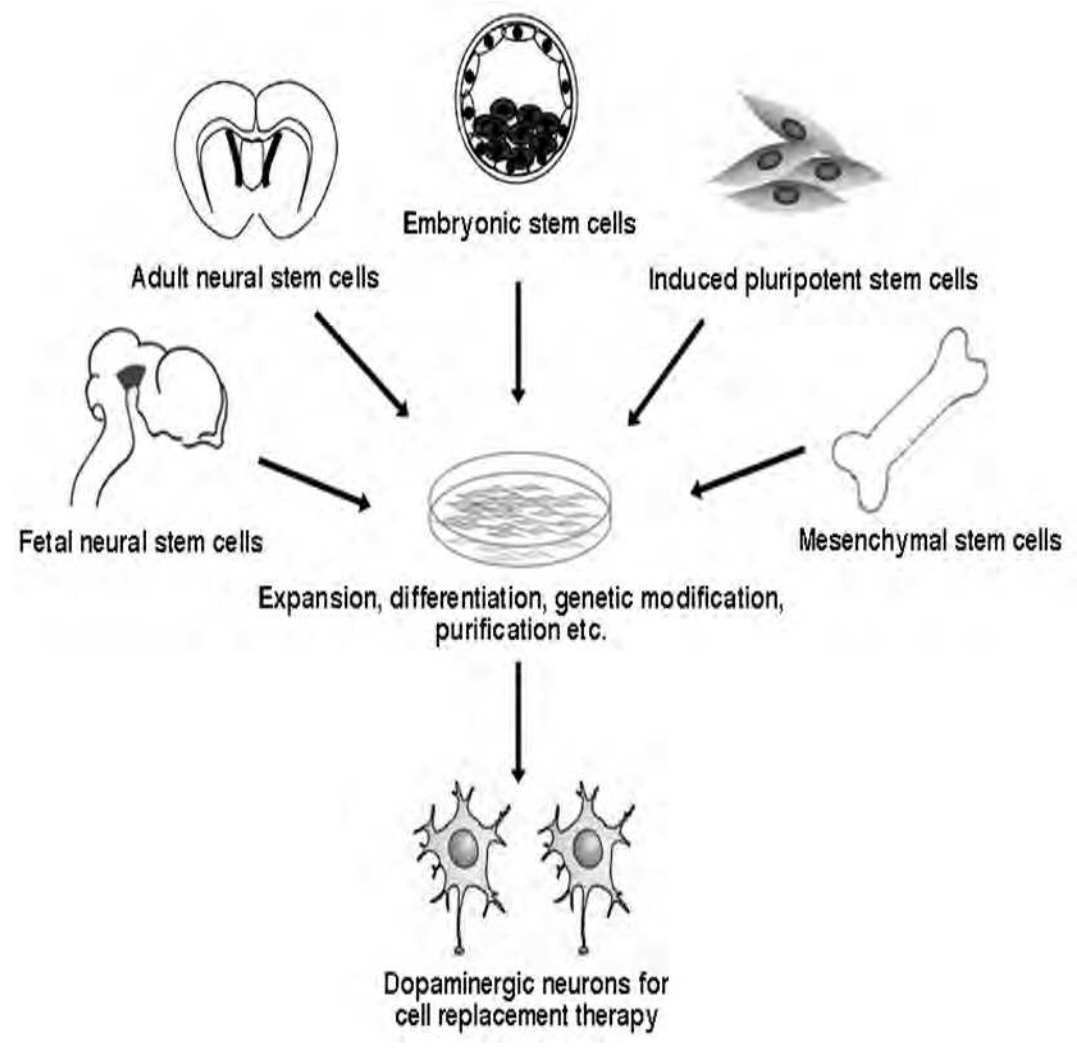

Fig. 1. Illustration of different types of stem cells considered for cell replacement therapy in Parkinson's disease. 
able to generate cells of all three germ layers. Somatic or tissue-derived stem cells can be isolated from developing tissues of the fetus or in the newborn, juvenile or adult organism. Somatic stem cells have a more limited proliferation capacity than ESCs and are termed multipotent, typically being able to differentiate into the different cell types of one germ layer. Potential groups of stem cells for cell therapy for PD include ESCs, neural stem cells (NSCs), mesenchymal stem cells (MSCs) and more recently induced pluripotent stem (iPS) cells, which all will be discussed separately in this section.

The most important question, using stem cells as a therapy for PD, remains whether it is possible to generate a large number of cells with the capacity to survive and function as dopaminergic neurons following transplantation and to be sure that these stem cell derived grafts do not show adverse effects such as tumor formation or immune rejection (Table 1).

\subsection{Embryonic stem cells}

Generally, human ESCs are considered the most promising source of stem cells for cell therapy in PD as well as other diseases, since they have several advantages to somatic stem cells. First, most somatic stem cells are difficult to isolate and propagate, whereas ESCs are easily derived and are able to grow almost indefinitely in culture. Second, ESCs can be genetically manipulated by homologous recombination to correct a genetic defect, whereas somatic stem cells only can be genetically manipulated through the introduction of viral transgenes. Third, ESCs can be guided into becoming any type of cell in the body through specific culture conditions, whereas the differentiation potential of somatic stem cells is much more restricted. The major limitation is ethical issues regarding the use of fertilized eggs for derivation of ESCs. The challenges in providing cells for replacement therapy for PD both lie in stimulating ESCs to form neurons and, afterwards to make these neurons differentiate into functional dopaminergic cells. Thus, several strategies have been used to differentiate ESCs into dopaminergic neurons in vitro. In 2000, two reports for the first time described the generation of midbrain dopaminergic neurons from mouse ESCs (Kawasaki et al. 2000; Lee et al. 2000). Kawasaki et al. (2000) used a co-culture strategy in which the ESCs were grown on a layer of bone marrow stromal cells (PA6) to induce neural differentiation and the generation of dopaminergic neurons. They named this neural inducing effect as stromal cell-derived inducing activity (SDIA). The study by Lee et al. (2000) was based on a five-stage protocol, based on the generation, and later differentiation of spherical aggregate structures called embryoid bodies and addition of different combinations of factors known to promote dopaminergic differentiation such as fibroblast growth factor 8 (FGF8), sonic hedgehog (Shh) and ascorbic acid. The co-culture system resulted in a yield of approximately $16 \% \mathrm{TH}$-positive cells (Kawasaki et al. 2000), whereas the five-stage protocol only resulted in around 5\% THpositive cells (Lee et al. 2000). In 2002, Kim et al. reported that $78 \% \mathrm{TH}$-positive cells could be generated in vitro by using the five-stage protocol if the mouse ESCs overexpressed the midbrain precursor transcription factor Nurr1 (Kim et al. 2002). Since then, several studies using non-genetic modification approaches for differentiation of mouse ESCs have followed by the co-culturing strategy, the five-stage strategy, or a combination of both, however the number of neurons adopting a dopaminergic phenotype has varied considerably (Barberi et al. 2003; Inden et al. 2004; Rodriguez-Gomez et al. 2007; Morizane et al. 2006). In order to deal with this inefficiency several groups have followed the example by Kim et al. (2002) and manipulated mouse ESCs to overexpressed genes know to promote the dopaminergic phenotype, such as Nurr1 (Sonntag et al. 2004; Chung et al. 2002), Pitx3 (Chung et al. 2005; 
Hedlund et al. 2008) and Lmx1a (Friling et al. 2009; Andersson et al. 2007), which have resulted in much higher yields of dopaminergic neurons. However, these transgenic approaches have limitations towards clinic use until the safety of such manipulations has been addressed.

In vivo studies have shown that it is possible to transplant ESCs into rodent models of PD and form dopaminergic neurons with a midbrain morphology that can ameliorate some of the motor symptoms (Rodriguez-Gomez et al. 2007; Barberi et al. 2003; Bjorklund et al. 2002; Kim et al. 2002; Hedlund et al. 2008). In 2002, Bjorklund et al. grafted undifferentiated mouse ESCs into the striatum of 6-OHDA-lesioned rats. Results showed that the grafted cells survived for 14-16 weeks and developed into midbrain-like dopaminergic neurons, thus the local inductive environment was indeed sufficient to induce dopaminergic differentiation of the undifferentiated ESCs. However, $20 \%$ of the grafted animals showed teratoma formation (Bjorklund et al. 2002). Several other studies have used different protocols for pre-differentiation of ESCs before transplantation (Shim et al. 2004; Nishimura et al. 2003; Kim et al. 2002) and prolonged in vitro differentiation seems to diminish the risk of tumor formation, but at the same time reduces survival of grafted cells as well as their the ability to integrate into the host tissue (Chung et al. 2002). In another approach, several groups focus on using fluorescence activated cell sorting (FACS) to select and purify midbrain dopaminergic neurons in the cell suspension before transplantation in order to minimize the risk of tumor formation (Hedlund et al. 2008; Chung et al. 2006).

Human ESCs can also be induced to become dopaminergic neurons both in vitro and in vivo. As for the mouse ESCs the most promising strategy for the generation of dopaminergic neurons has been co-culture systems (Perrier et al. 2004; Zeng et al. 2004) as compared to the multiple-stage method (Carpenter et al. 2001; Zhang et al. 2001). In 2004, Perrier et al. reported a very successful protocol for the generation of dopaminergic neurons from human ESCs. In this protocol the human ESCs were co-cultured with bone marrow stromal cells and treated in a sequential manner with patterning and differentiation molecules, including FGF8, Shh, FGF2, brain-derived neurotrophic factor (BDNF), glial cell line derived neuroptrophic factor (GDNF), transforming growth factor (TGF)- $\beta 3$, dibutyryl-cAMP, and ascorbic acid. This treatment resulted in a yield of $65-80 \%$ TH-positive cells out of total neurons. Moreover, the dopaminergic neurons expressed several midbrain dopaminergic markers, released dopamine, had TH-positive synaptic terminals, and showed the presence of depolarization-induced and tetrodotoxin sensitive actions potentials, indicating that these cells were truly functional midbrain dopaminergic neurons (Perrier et al. 2004). More recently, great efforts have been put into defining chemical conditions that enhance dopaminergic differentiation in order to get rid of feeder layers and co-culture that compromise clinical use (Iacovitti et al. 2007; Song et al. 2008). Interestingly, a study by Vazin et al. (2009) identified four factors secreted from mouse stromal PA6 cells that are often used as feeder cells in the co-culture system, and these factors greatly enhanced the generation of neurons including the dopaminergic phenotype from human ESCs when added to the medium.

Dopaminergic neurons derived from human ESCs have also been transplanted into rodent models of PD, but the number of surviving TH-positive cells has been very low, and many of the transplants have shown evidence of proliferating cells and teratoma formation (Ben-Hur et al. 2004; Park et al. 2005; Zeng et al. 2004). Hence, improving the survival of the grafted human ESCs is a major challenge that has to be overcome before clinical application of the cells is possible. Interestingly, Roy et al. 2006 found a significant improved generation of TH-positive 
cells (up to $67 \%$ of total cells counted), when the human ESCs were cultured according to a feeder-based protocol in which human midbrain astrocytes were used to induce dopaminergic differentiation. These cells induced a significant behavioural recovery when transplanted into the striatum of parkinsonian rats. The dopaminergic neurons were reported to survive for 8 weeks, however neural tissue overgrowth and neuroepithelial tumors were found (Roy et al. 2006). More recent studies, using longer differentiation periods have produced larger numbers of dopaminergic neurons in the transplants (Yang et al. 2008).

As described above, the use, growth and differentiation of ESCs are not without disadvantages, and the use of fertilized eggs raise ethical concerns and limitations. In order to use human ESCs in the clinic it is important to culture the ESCs in xeno-free systems, which have not been the case for several existing protocols. However, as discussed above this issue has started to be resolved by production of chemically defined medias. Other problems that need to be solved before clinical use are the low survival and maintenance of the transplanted human ESC-derived dopaminergic neurons, and in addition the high risk of teratoma formations or other kinds of uncontrolled cell growth such as tumors by residual undifferentiated cells. Moreover, the risk of immune rejection questions the safety of clinical application of human ESCs.

\subsection{Neural stem cells}

NSCs are multipotent stem cells derived from neural tissues, which have the ability to selfrenew and give rise to cells restricted to the neuronal and glial lineages, namely neurons, astrocytes and oligodendrocytes. Such NSCs are found in the developing nervous system and in certain regions of the adult brain. One advantage of NSCs as compared to ESCs is that they are less likely to form tumors after transplantation, since they are not pluripotent and capable of unlimited proliferation, and they seem to be more genomically stable than ESCs (Maitra et al. 2005; Draper et al. 2004). Both ESCs and fetal or adult NSCs represent potential cell sources for therapy, which and will be described and discussed in the following paragraphs (Fig. 2).
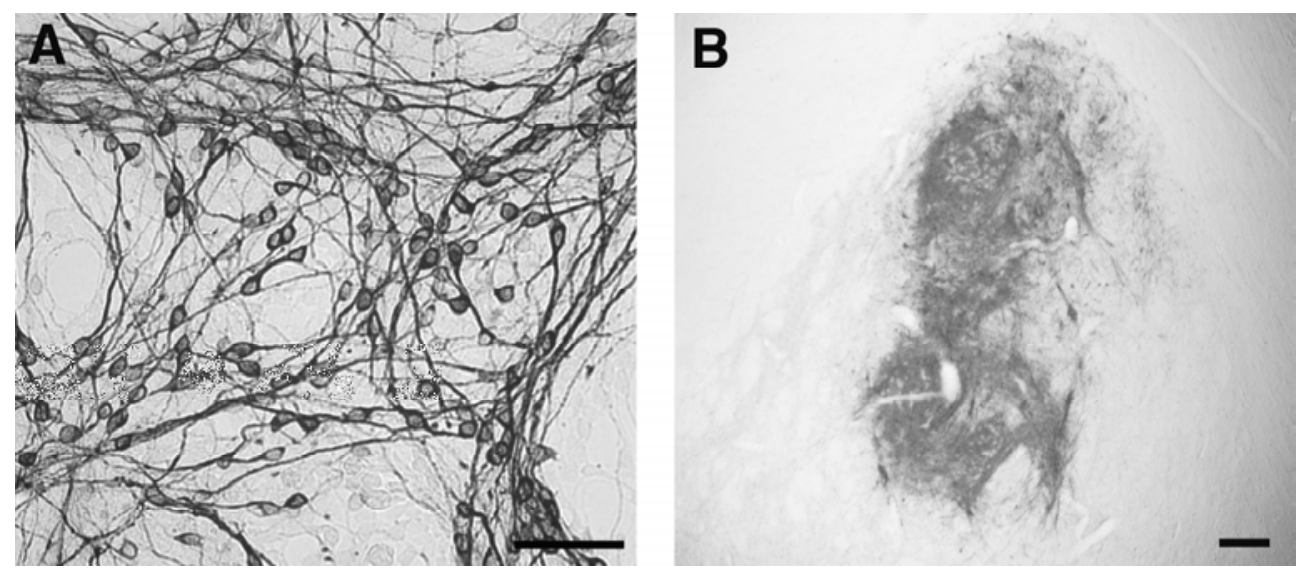

Fig. 2. A) In vitro differentiated TH-positive dopaminergic neurons generated from human neural stem cells. B) Intrastriatal porcine neural tissue graft containing TH-positive dopaminergic neurons in a rat model of Parkinson's disease. Scale bars $200 \mu \mathrm{m}$. 


\subsubsection{NSCs cells in the embryonic brain}

NSCs from the developing central nervous system proliferate in response to similar growth factors regardless of which part of the brain they originate. However, they are not equivalent to each other and seem to maintain certain region-specific properties, even after they have been cultured in vitro for prolonged periods (Ostenfeld et al. 2002; Hitoshi et al. 2002; Schwarz et al. 2006). Hence, the most obvious place to look for stem cells able to generate dopaminergic neurons for PD is in the developing midbrain. Stem cells from this area are more likely to show a similar phenotype, and should have a straightforward differentiation pathway to form midbrain specific dopaminergic neurons (Ostenfeld et al. 2002; Horiguchi et al. 2004).

As previously described (section 2.2.2), PD patients have been successfully transplanted with ventral mesencephalic tissue from embryos at different stages. However, tissue from several human embryos is required for each patient due to the poor survival of the grafted neurons, thus resulting in practical-logistic problems. To overcome this problem several groups have focused on the idea of expanding ventral mesencephalic tissue to reduce the number of fetuses required for transplantation of one patient. In 1998, Studer et al. isolated neural precursor cells from the rat ventral mesecephalon and successfully expanded these cells by use of the mitogen FGF2, resulting in a 10-fold increase in the total number of cells and a 3-fold increase in the number of dopaminergic neurons. When transplanted into the striatum of 6-OHDA-lesioned rats the cells induced functional recovery. However, despite these promising results the general survival of grafted dopaminergic neurons was only around 3-5\% (Studer, Tabar, and McKay 1998). Subsequently, the proportion of TH-positive cells generated by this method was further increased by culturing the cells at physiologically low oxygen tension (Studer et al. 2000). Carvey et al. 2001 reported a generation of 20-25\% TH-positive cells from rat embryonic ventral mesencephalic precursor cells by using a combination of the cytokines IL-1 and IL-11, leukemia inhibitory factor and GDNF. They further expanded these cells and found clones containing up to $98 \% \mathrm{TH}$-positive cells and these were selected for transplantation into the striatum of 6-OHDA lesioned rats. The grafts completely reversed the rotational asymmetry, however, as seen in the study by Studer et al. (1998), the survival of the differentiated cells was very poor (Carvey et al. 2001).

In order to enhance the generation of midbrain specific dopaminergic neurons as well as increase the survival of these cells after transplantation genetic modification is an attractive strategy. In an early study, overexpression of Nurr1 in an immortalized NSC line originally derived from the mouse cerebellum showed a robust generation of dopaminergic neurons when these cells were co-cultured with astrocytes of mesencephalic origin (Wagner et al. 1999). Rat forebrain precursors have been reported to differentiate into dopaminergic neurons after genetic modification to co-express Nurr1, Shh and Bcl-xL or Nurr1 and Mash1, and these cells also showed behavioral benefits after transplantation into 6-OHDA- lesioned rats (Park et al. 2006). Overexpression of Nurr1 in NSCs derived from the rat ventral mesencephalon have been shown to result in 5\% TH-positive neurons (Kim et al. 2007), whereas co-expression of Nurr1 and Neurogenin 2, another transcription factor important for development of mesencephalic dopaminergic neurons, did not mediate additional positive effect on the yield of TH-positive cells, but increased maturation of the dopaminergic phenotype (Andersson et al. 2007). In contrast, another study did not find increased generation of dopaminergic neurons after retroviral induction of rat mesencephalic derived NSCs with Lmx1a, Msx1, Neurogenin 2 and Pitx3 (Roybon et al. 2008). Single expression of each of these genes was not enough to promote dopaminergic 
differentiation and dual overexpression of Lmx1a and one of the other transcription factors also failed to generate dopaminergic neurons. The authors suggest that NSC harvested from this rather late (embryonic day 14.5) stage of development have lost their potential to be driven into a specific neuronal phenotype, thus NSC from a earlier time point or ESC may be better candidates for generation of dopaminergic neurons (Roybon et al. 2008).

Initial attempts to expand human NSCs from the developing mesencephalon only generated low numbers of dopaminergic neurons, which was also seen after transplantation into 6OHDA-lesioned rats (Svendsen et al. 1997). Subsequently, an increased yield of dopaminergic neurons was found by culturing the human NSCs at low oxygen tension with further induction of differentiation by IL-1, IL-11, leukemia inhibitory factor and GDNF, but survival and possible in vivo functional effects were not addressed (Storch et al. 2001). Interestingly, Wang et al. (2004) showed that pre-differentiation of human mesencephalic NSCs with FGF8, GDNF and forskolin resulted in $26 \%$ TH-positive cells as compared to $1.4 \%$ in non-differentiated cultures in vitro and furthermore, the pre-differentiated cells showed increased functional recovery after transplantation (Wang et al. 2004). The yields of TH-positive cells (up to 60\%) have been further improved by using a combination of BDNF, dopamine and forskolin with either retinoic acid or GDNF (Riaz et al. 2004), whereas other studies only have managed to generate 4-25\% TH-positive neurons using a combination of different differentiation factors (Christophersen et al. 2006; Yang et al. 2004). These two studies also found very low numbers of surviving TH-positive cells following transplantation into 6-OHDA-lesioned rats, and it remains unclear if this is due to loss of TH expression or death of TH-positive cells after transplantation.

Another approach to obtain large numbers of human dopaminergic neurons for transplantation is to generate immortalized cell lines by genetic modification, thus such cell lines offer a theoretically unlimited source of specific NSCs. Some NSC lines have shown to generate around 20\% TH-positive cells (Paul et al. 2007; Lotharius et al. 2002), but when these cells were transplanted into immunosuppressed 6-OHDA-lesioned rats they either died or loose TH expression (Paul et al. 2007). In order to enhance dopaminergic survival further genetic modifications can be added, such as overexpression of $\mathrm{Bcl}-\mathrm{xL}$, an antiapoptotic protein stimulating commitment and survival of dopaminergic neurons (Liste, Garcia-Garcia, and Martinez-Serrano 2004; Krabbe et al. 2009). Such immortalized cells serve as important model cell lines or tools for basic stem cell research, but several safety issues have to be resolved if such cell lines should be considered for clinical use.

\subsubsection{NSCs in the adult brain}

The human brain is traditionally classified as a non-renewable organ unable to replace damaged or degenerated cells. Neurogenesis in the adult rat brain was first described in the early 1960s by Joseph Altman (Altman and Das 1965), but general acceptance of this neurogenesis was not made until the early 1990s (Reynolds and Weiss 1992). One major advantage of using NSCs from the adult brain compared to those from the embryonic brain is that it would abolish all ethical concerns regarding the use of embryonic tissue.

In the adult mammalian brain NSCs are mainly found in the subventricular zone (SVZ) of the lateral ventricles (Lois and Alvarez-Buylla 1994; Morshead et al. 1994) and the subgranular zone of the hippocampal dentate gyrus (Bayer, Yackel, and Puri 1982; Palmer, Ray, and Gage 1995). From the SVZ, neuroblasts migrate a long distance anteriorly, through the rostral migratory stream, to their final destination in the olfactory bulb, where they 
mature into local interneurons as reported both in rodents (Lois and Alvarez-Buylla 1994) and in humans (Curtis et al. 2007). Newly generated cells in the subgranular zone migrate to the granular layer of the dentate gyrus, where they replace degenerated neurons and extend projections to the CA3 area of the hippocampus (Bayer, Yackel, and Puri 1982). Several studies have shown that neurogenesis also occur, although at much lower levels, in other areas of the adult mammalian nervous system, such as the cerebral cortex (Palmer et al. 1999), hypothalamus (Markakis et al. 2004), septum (Palmer, Ray, and Gage 1995), retina (Tropepe et al. 2000), optic nerve (Palmer et al. 1999), spinal cord (Weiss et al. 1996), and more debatable in the substantia nigra harbouring the dopaminergic neurons that degenerate in PD (Zhao et al. 2003). As indicated, some controversy remains in relation to the substantia nigra since other research groups have not been able to replicate some of these results (Lie et al. 2002; Frielingsdorf et al. 2004). Lie et al. (2002) found no evidence of either newly generated dopaminergic in the adult rat substantia nigra or neurons of any type in vivo. However, when cells from this region were removed and grown in vitro, they became capable of neuronal production, indicating that this potential may be inhibited by endogenous signals in the adult brain (Lie et al. 2002). Hermann et al. (2006) have shown the presence of multipotent NSCs in the adult mouse tegmentum (midbrain and hindbrain region) with capacity to differentiate in vitro into functional neurons, including the dopaminergic phenotype (Hermann et al. 2006). Thus, the potential existence adult NSCs in the substantia nigra cannot be denied until further clarification has taken place. Despite the presence of endogenous NSCs, the self-repairing activity of the adult mammalian brain is poor. This may be explained by microenvironmental factors present in most areas of the adult brain, which inhibit neural differentiation of NSCs, or by a too small number of endogenous NSCs for effective self-repair.

So far, attempts to develop dopaminergic neurons from NSCs from adult tissue have only been moderately successful both in vitro and in vivo. In one study NSCs from the SVZ were stimulated to become dopaminergic neurons using a protocol for midbrain dopaminergic induction of ESCs (5-stage method involving addition of Shh and FGF8). It was found to be possible to generate neurons displaying some characteristics of immature dopaminergic neurons, however these cells were limited in their capacity to generate mature dopaminergic neurons showing exclusively a midbrain phenotype (Papanikolaou et al. 2008). Similarly, in vivo studies in which adult NSCs have been transplanted into rodent models of PD indicate that any behavioral recovery is due to the general neuroprotective effect of the non-neuronal grafted cells, more than the presence of stem cell derived dopaminergic neurons in the grafts (Richardson et al. 2005; Dziewczapolski et al. 2003).

An alternative strategy is to stimulate endogenous NSCs to differentiate into dopaminergic neurons either in the striatum or the substantia nigra. So far attempts to stimulate the development of new neurons in the 6-OHDA-lesioned rats striatum have not been successful. Some studies have shown that TGF $\alpha$ can stimulate neurogenesis and migration to the striatum, but none of these cells were of dopaminergic or other neuronal phenotypes (Cooper and Isacson 2004; de Chevigny et al. 2008). Ideally, stimulation of neurogenesis in the substantia nigra could reconnect the basal ganglia circuitry and hence increase functional recovery in PD. However, although there might be NSCs in the adult substantia nigra (Zhao et al. 2003) it is only a very small pool of cells insufficient to replace the dopaminergic neuron loss during progressive PD. Moreover, even if it is possible to stimulate neurogenesis in the substantia nigra lack of long-distance axonal growth, along the degenerated nigrostriatal projections, remains a very challenging problem. 


\subsection{Mesenchymal stem cells}

From an immunological and ethical prospective it would be ideal if stem cells could be harvested from, for instance, the patient's own bone marrow and then be used to generate neurons for transplantation. The adult bone marrow contains at least two kinds of stem cell populations: hematopoietic stem cells and mesenchymal stem cells (MSCs) also called bone marrow stromal cells. Hematopoietic stem cells continually repopulate the circulation by differentiating into erythroid, myeloid, and lymphoid lineages, whereas MSCs give rise to mesenchymal derivatives, including osteocytes, chondrocytes, adipocytes and myocytes (Pittenger et al. 1999). MSCs are found only in low numbers in the bone marrow (around 1 MSC per 100 mononuclear marrow cells). They can be purified, from other cells in the bone marrow, on the basis of their ability to adhere to plastic surfaces (Reyes et al. 2001). MSCs are like other stem cells capable of self-renewal, but it has been proposed that self-renewal is less crucial for the physiology of mesenchymal tissue as are multipotentiality and phenotypic flexibility, which indicates that commitment and differentiation are reversible in response to environmental cues. MSCs display the ability of interconversion from one cell type to another at a later differentiation stage than that of other multipotent stem cells (Park, Oreffo, and Triffitt 1999; Beresford et al. 1992). One reason for this potential could be that it is necessary for bone modelling and remodelling (Bianchi et al. 2001).

Several studies provide evidence that MSCs can be induced to overcome their mesenchymal fate and break the barrier of germ layer commitment by transdifferentiation into cell types of other germ layers (Krabbe, Zimmer, and Meyer 2005). In fact, it has been proposed that MSCs have a neural predisposition, since they express neural markers such as neuron specific-enolase, neuronal nuclei, nestin, glial acidic fibrillary protein and TH at basal levels (Blondheim et al. 2006). However, both the transdifferentiation potential of MSCs and the indication that these cells should be biological neurons are controversial. Evidence of a "neuronal" MSC is considered weak and what seems to be transdifferentiation may be explained by a stress response causing a rapid disruption of the actin cytoskeleton with cell shrinkage as a result (Neuhuber et al. 2004) or by cell fusion, in which MSCs have fused with other cell types rather than switching lineage identity (Lu, Blesch, and Tuszynski 2004; Terada et al. 2002).

Nevertheless, efforts are still being made to generate functional neuronal cells from MSCs, and at the beginning of the millennium several research groups have reported that it was possible to induce both human, rat and mouse MSCs to differentiate into neuron-like cells in vitro (Black and Woodbury 2001; Deng et al. 2001; Kohyama et al. 2001; Sanchez-Ramos et al. 2000; Woodbury et al. 2000; Munoz-Elias, Woodbury, and Black 2003). Moreover, MSCs were found to migrate and differentiate in a neural-like manner, when transplanted into rat (Azizi et al. 1998) or mouse (Kopen, Prockop, and Phinney 1999) brains, suggesting that the cells, at least theoretically, may represent a future source of cells for treatment of neurodegenerative disorders.

If MSCs are going to be used as a cell source for cell therapy of PD it is important to differentiate these cells into functional dopaminergic neurons, which have been investigated by different strategies. Several groups have induced MSCs by adding cocktails of extrinsic factors to the culture medium (Barzilay et al. 2008; Hermann, Maisel, and Storch 2006; Tatard et al. 2007; Trzaska, Kuzhikandathil, and Rameshwar 2007; Trzaska et al. 2009), others by co-culturing of the MSCs with specific cell types (Jiang et al. 2003), or by genetic manipulation of the cells (Dezawa et al. 2004). From a therapeutically point of view the first mentioned strategy has some advantages, since the cells are not transformed or co-cultured 
with other cell-types making the cell transplantation more safe. In 2007, Trazska et al. found an effective protocol for dopaminergic differentiation of MSCs in which a cocktail of FGF8, Shh and bFGF were added to the medium. About $67 \%$ of the cells expressed the dopaminergic marker $\mathrm{TH}$ along with other dopaminergic markers. Moreover, the cells secreted dopamine, but without showing further evidence of being functional mature dopaminergic neurons, and hence they were called dopaminergic progenitors (Trzaska, Kuzhikandathil, and Rameshwar 2007). These results were supported by Barzilay et al. (2008), who tested 20 different protocols for dopaminergic induction of MSCs. They found that the most significant upregulation of TH expression was obtained using BDNF either alone or in combination with GDNF, TGF- $\beta 3$ and retinoic acid. However, as described by Trzaska et al. (2007), the TH-positive cells did not show mature functional dopaminergic neuron characteristics (Barzilay et al. 2008). In 2009, Trzaska et al. investigated potentially factors that could stimulate the dopaminergic maturation of the cells and found that the MSC-derived neuronal cells showed robust upregulation of tropomyosin-receptor-kinase B beginning at day 9 of the induction. One factor which is known to be involved in the maturation of dopaminergic neurons and which binds to this receptor is BDNF (Baquet, Bickford, and Jones 2005). Hence, they added BDNF to the medium after 9 days of induction and found generation of cells that elicited spontaneous post-synaptic current and secreted dopamine in response to $\mathrm{Ca}^{2+}$-dependent depolarization. These findings show that the MSCderived dopaminergic neurons can mimic the physiology of native neurons. Moreover, $\mathrm{BDNF}$ treatment resulted in $\mathrm{KCl}$-induced depolarization and enhanced dopamine release. They also investigated whether the BDNF-treated cells responded to neurotransmitters such as GABA, acetylcholine and glutamate and found that the BDNF-treated cells responded to both acetylcholine and GABA, but not glutamate. However, the way they responded to GABA and the lack of response to glutamate indicates that these cells were still developing and not fully mature (Trzaska et al. 2009).

All the studies mentioned above indicate that generation of dopaminergic neurons from MSCs may be possible, but to candidate as donor cells for PD, it still remains to be elucidated if the cells contain the entire dopaminergic machinery present in functional dopaminergic neurons in vivo.

\subsection{Induced pluripotent stem cells}

For a long time ESCs have been considered the most promising source of cells for future cell replacement therapy in PD. However, ethical concerns regarding the use of human embryos and the possibility of immune rejection due to immunological incompatibility between patient and donor ESCs may limit their use. To overcome these problems scientists have worked on the development of pluripotent stem cells from adult somatic cells, involving genetic changes (reprogramming) of the somatic cell nucleus. Until recently, reprogramming of cells involved cloning of cells by somatic cell nuclear transfer, where the nucleus in an oocyte is replaced with the nucleus from an adult somatic cell (Wilmut et al. 1997) or by fusion of an adult somatic cell with an ESC (Cowan et al. 2005). However, besides being both time consuming and technical difficult this kind of reprogramming still requires the use of human oocytes or ESCs and hence do not solve the ethical problems.

In 2006, Takahashi and Yamanaka reported for the first time that it was possible to reprogram adult mouse fibroblasts to pluripotent stem cells by retroviral transduction with the four transcription factors Oct3/4, Sox2, c-Myc and Klf4, which are highly expressed in ESCs (Takahashi and Yamanaka 2006). The resulting so-called induced pluripotent stem 
(iPS) cells share several properties with ESCs, including morphology, growth properties and pluripotency, defined by their ability to form teratomas in vivo and differentiate into distinct cell types of all three germ layers, but they are not identical to ESCs when it comes to epigenetic status (Deng et al. 2009) and gene expression (Chin et al. 2009). In addition, the original iPS cells failed to generate postnatal chimeras and contribute to the germline (Takahashi and Yamanaka 2006), but refinement of the method for selection of iPS cells has already solved these issues and moreover, the resulting iPS cells are even more similar to ECSs at the epigenetic level (Okita, Ichisaka, and Yamanaka 2007; Maherali et al. 2007; Meissner, Wernig, and Jaenisch 2007). Shortly after these initial studies in mice, iPS cells were derived from human fibroblasts using slightly different combinations of genes (Takahashi et al. 2007; Yu et al. 2007) and since then, iPS cells have been generated from a number of different cell types and species (Masip et al. 2010).

The similarities of iPS cells to ESCs, and the fact that these cells can be generated from the patient's own cells, make them very attractive candidates for cell-based therapy. However, before iPS cells can be used in the clinic there are several issues that need to be resolved. First, it is extremely important to optimize the procedure for reprogramming of the somatic cells. As described above, many groups have generated iPS cells by use of retroviral vectors. Since retrovirus integrates randomly in the DNA it may alter the differentiation potential or even induce malignant transformation of the iPS cells. Moreover, most research groups have used c-Myc as one of the reprogramming factors and since c-Myc is a proto-oncogene, its reactivation could give rise to transgene-derived tumor formation. In one study $20 \%$ out of 121 mice derived from an iPS cell line developed tumors. In these tumors, retroviral expression of c-Myc, but not Oct3/4, Sox2, or Klf4 was reactivated (Okita, Ichisaka, and Yamanaka 2007). Hence, recent studies have focused on developing safer reprogramming strategies, for example, by generation of iPS cells without using the c-Myc oncogene. In 2008, Nakagawa et al. generated iPS cell lines from both mouse and human fibroblasts without the use of c-Myc. They found that it was possible to generate cells expressing ESC markers, and that the induction of the fibroblasts to iPS cells was more specific, since a lower number of non-iPS cells were generated. However, efficiency of the generation process was substantially reduced with the omission of c-Myc. They also examined the tumourigenicity in mice derived from these cells and found that omission of the c-Myc retrovirus significantly reduced the risk of tumorigenicity in chimeras (Nakagawa et al. 2008). Other studies have also examined different combinations of transcription factors, and of the original four transcription factors, Oct3/4 is the only one that cannot be replaced by other transcription family members and have been required in every reprogramming strategy in both mouse and human cells. Other strategies have been to generate iPS cells using integration systems such as plasmids (Kaji et al. 2009) and transposons (Woltjen et al. 2009), which allow removal of these systems after reprogramming. Moreover, iPS cells have also been generated without genomic integration using nonintegrative adenoviral vectors (Zhou and Freed 2009; Stadtfeld et al. 2008), repeated plasmid transfection with or without the use of small molecules (Okita et al. 2010; Okita et al. 2008; Yu et al. 2009) and just addition of recombinant proteins (Zhou et al. 2009; Kim et al. 2009). Although, these methods are not yet as efficient as the retroviral approach, they have clearly shown that random DNA mutagenesis is not a requirement for reprogramming and give hope for the development of clinically applicable iPS cells free of viruses and transgenic integration.

Interestingly, a recent publication have shown a method for direct reprogramming of fibroblasts into neurons, avoiding generation of undifferentiated cells and their following 
differentiation (Vierbuchen et al. 2010). They started from a pool of nineteen neural-lineage specific transcription factors and identified a combination of only three factors (Mash1, Brn2 and Myt1l) that were sufficient to convert mouse fibroblasts into functional neurons in vitro. Such induced neurons clearly have some advantages to iPS cells, since they avoid generation of pluripotent cells that can give rise to tumors. In this study the induced neurons mainly gave rise to GABAergic neurons after differentiation, but their regional identity is still unclear (Vierbuchen et al. 2010). This strategy offers new perspectives to the reprogramming field and future studies need to determine if certain cell types are more useful in generation of specific cells for replacement strategies and if it is necessary to reprogram cells all the way back to pluripotent stem cells.

\begin{tabular}{|c|c|c|}
\hline & Advantages & Disadvantages \\
\hline ESCs & $\begin{array}{l}\text { - Unlimited proliferation } \\
\text { capacity } \\
\text { - } \quad \text { Potential to generate any cell } \\
\text { type (pluripotent) } \\
\text { - } \quad \text { Generation of stem cell banks }\end{array}$ & $\begin{array}{ll}\text { - } & \text { Risk of teratomas (heterogenous } \\
\text { composition) } \\
\text { - } & \text { Time demanding/complex } \\
& \text { differentiation into dopaminergic } \\
\text { - } & \text { neurons } \\
\text { - } & \text { Risk of immune rejection } \\
\text { Ethical issues }\end{array}$ \\
\hline NSCs & $\begin{array}{ll}\text { - } & \text { Restricted differentiation } \\
\text { potential (multipotent) } \\
\text { - } \quad \text { Low risk of tumor formation }\end{array}$ & $\begin{array}{ll}\text { - } & \text { Limited proliferation capacity } \\
\text { - } & \text { Reduced neuronal differentiation } \\
& \text { capacity following long-term } \\
& \text { proliferation } \\
\text { - } & \text { Risk of immune rejection } \\
\text { - } & \text { Ethical issues (fetal NSCs) } \\
\end{array}$ \\
\hline MSCs & $\begin{array}{ll}\text { - } & \text { Easily harvested } \\
\text { - } & \text { Possibility of generating } \\
& \text { patient specific cells } \\
\text { - } & \text { No ethical concerns }\end{array}$ & $\begin{array}{l}\text { - Differentiation into "truly" } \\
\text { functional dopaminergic neuron } \\
\text { still uncertain }\end{array}$ \\
\hline $\begin{array}{l}\text { iPS } \\
\text { cells }\end{array}$ & $\begin{array}{ll}\text { - } & \text { Unlimited proliferation } \\
\text { - } & \text { Potential to generate any cell } \\
\text { - } & \text { type (pluripotent) } \\
\text { - } & \text { Poneration of stem cell banks } \\
& \text { patient specific cells } \\
\text { - } & \text { No risk of immune rejection } \\
\text { - } & \text { No ethical concerns }\end{array}$ & $\begin{array}{ll}\text { - } & \text { Risk of teratoma (heterogenous } \\
\text { composition) } \\
\text { - } \\
\text { Risk of tumor formation (viral } \\
\text { transduction) } \\
\text { Time demanding/complex } \\
\text { differentiation into dopaminergic } \\
\text { neurons } \\
\text { - Expensive procedure }\end{array}$ \\
\hline
\end{tabular}

Table 1. Overview of advantages and disadvantages of different types of stem cell for cell replacement therapy in Parkinson's disease.

\subsection{1 iPS cells and Parkinson's disease}

The therapeutic potential of human iPS cells for cell-based therapy of PD relies on efficient differentiation of iPS cells into functional midbrain dopaminergic neurons. Several groups have worked on generation of dopaminergic neurons from iPS cells in vitro. In 2008, Wernig et al. showed that mouse fibroblast-derived iPS cells predifferentiated into dopaminergic 
neurons could integrate into the host striatum of parkinsonian rats and lead to functional improvements (Wernig et al. 2008). However, these cells also led to teratoma formation as seen after transplantation of ESCs - likely due to the presence of undifferentiated cells (Roy et al. 2006). The occurrence of pluripotent cells was reported to be the most likely cause of teratoma formation in the Wernig et al. study, since viral transcripts were not reactivated in the tumors. Furthermore, they showed that eliminating the undifferentiated cells before transplantation (by depletion of SSEA1-positive cells by FACS) could significantly reduce the risk of tumor formation (Wernig et al. 2008). More recent studies have shown as efficient generation of dopaminergic neurons from human iPS cells as from ESCs, which subsequently could survive and integrate in the host striatum of parkinsonian rats (Swistowski et al. 2010; Cai et al. 2010). In one study, functional recovery of the parkinsonian rats was also reported and furthermore, genome-wide microarray comparison between human iPS cells, ESCs and dopaminergic neurons derived from both sources revealed overall similarity (Swistowski et al. 2010).

Interestingly, the iPS cell technology also provides the basis for development new disease models, since they can be generated from patients with specific diseases. Although, iPS cells can be used for both sporadic and genetic diseases, they might be of particular advantage for diseases with a solid genetic background and/or which occur early in development. Some studies have generated iPS cells from patients suffering from sporadic PD (Park et al. 2008; Soldner et al. 2009). Soldner et al. (2009) developed dopaminergic neurons from iPS cells derived from patients with PD as efficiently as iPS cells from healthy individuals and did not report any phenotypic differences, thus the disease derived cells did not show any specific features of PD in vitro. The average age of onset of PD is more than 50 years, hence in vitro cell culturing periods of weeks or months may be too short for a pathologic phenotype to arise. However, although it takes many years for the pathologic characteristics to become evident, the disease process might be initiated much earlier, and therefore iPS cells offer the possibility of establishing a new type of disease model to investigate such issues. Indeed, it will be very important to investigate if iPS cells derived from patients are more susceptible to develop PD-like features than fetal tissue after grafting in PD patients (see section 2.2.2.3). Recently, differentiation of the patient-derived iPS cells described by Soldner et al. (2009) into dopaminergic neurons were shown to survive and mediate functional effect after transplantation into a rat model of PD (Hargus et al. 2010).

\subsection{Stem cells releasing therapeutic molecules ("cell factories")}

Instead of acting as a source of cells for neuronal replacement an alternative use of stem cells for transplantation is as so-called "cell factories" releasing neurotrophic and neuroprotective factors. Several neurotrophic factors have been shown to stimulate survival and/or differentiation of nigral dopaminergic neurons in vitro and in vivo, which is beyond the aim of this chapter to describe in detail but reviewed elsewhere (Evans and Barker 2008; Levy et al. 2005). Among neurtrophic factors, GDNF and some of the GDNF family members have shown the greatest promise as therapeutic agents for PD. Several studies have shown that GDNF can protect against nigrostiatal lesions in animal models. For instance, intravenous administration of MSCs overexpressing GDNF in mice before lesioning with MPTP has been shown to protect dopaminergic neurons in the substantia nigra as well as their striatal fibers (Park, Eglitis, and Mouradian 2001). In agreement with this observation, another study has shown that GDNF-producing mouse NSCs transplanted into the mouse striatum 16 days 
prior to 6-OHDA lesioning could prevent death of dopaminergic neurons and resulted in a reduced behavioral impairment (Akerud et al. 2001). A similar protective effect was found by overexpressing Neurturin, another member of the GDNF family, in the same NSC line (c17.2 NSCs derived from the mouse cerebellum) (Liu et al. 2007).

NSCs are considered very suitable for ex vivo gene delivery, since they can be cultured, differentiated into specific neuronal subtypes, transduced and selected for subsequent transplantation to the brain where they can migrate and extend projections. Human NCSs genetically modified to overexpress GDNF in an inducible way have been shown to express GDNF for up to 3 month in the brains of rodents and aged primates (Behrstock et al. 2006). Furthermore, transplantation of these cells after a partial lesion of the dopamine system resulted in increased host dopamine neuron survival and fiber outgrowth. MSCs are also very suitable as neuroprotective cells through secretion of neurotrophic factors and furthermore, these cells can easily be harvested from the patient's own bone marrow in order to avoid immune rejection. Along this line, Sadan et al. (2009) have recently developed a protocol to induce MSCs into neurotrophic factor-secreting cells, especially producing GDNF and BDNF without genetic modification of the cells.

Another way to overcome problems of host immunoresponses when using allografts, is the development of new materials to encapsulate transplanted cells, thereby serving as a biological shield to prevent immune rejection and eliminate the need for immunosuppression. The encapsulating material should allow inward diffusion of nutrients to the transplanted cells and at the same time permit outward secretion of trophic factors. Besides protection from the host immune system, these capsules have the advantage that they can be removed for safety reasons or for renewal of cells. Several studies have reported successful delivery of GDNF from encapsulated cells (Kishima et al. 2004; Tseng et al. 1997; Sagot et al. 1996; Ahn et al. 2005). Kishima et al. (2004) found a transient recovery in motor function after intraventricular infusion of encapsulated GDNF-producing cells in MPTP lesioned baboons, however no neuroprotection against the toxin was found. The lack of neuroprotective effect may be due to the intraventricular placement of the capsules resulting in inefficient passage of GDNF to the striatum, thus better graft sites should be used. Furthermore, they reported GDNF release and survival of encapsulated cells for more than 1 year after transplantation (Kishima et al. 2004).

Delivery of neurotrophic factors by co-grafted genetically modified stem cells or cell lines may also serve as a useful tool for stimulation of functional integration and protection of grafted dopaminergic neurons from any source. In one study, Ahn et al. (2005) tested such a strategy by co-grafting an encapsulated cell line overexpressing GDNF with human fetal mesencepahlic tissue into 6-OHDA lesioned rats, leading to increased fiber outgrowth in areas between the capsules and the grafts. This result indicates that continuous delivery of GDNF or other important neurotrophic factors via encapsulated genetically modified cells could further optimize neural transplantation as a therapy for PD.

\section{Conclusion}

Neural transplantation has emerged as a potential therapy for Parkinson's disease (PD). In experimental studies based on animal models and PD patients, various sources and types of donor cells have been investigated for their potential applicability. Clinical studies performed during the 1980s and 1990s, where dopaminergic neurons derived from human fetal brain tissue were transplanted into striatum of patients with PD, provided proof-of- 
concept that long-lasting therapeutic benefits can be achieved. Subsequent studies, in particular two double-blind placebo-controlled trials, showed variable and mostly disappointing results. They also revealed that some patients develop graft-induced dyskinesias as side effects. Thus, while nigral transplants clearly work well in certain PD patients, the technique needs refinement before it can successfully be applied on a large series of patients. This optimization includes patient selection (age, medical history, response to L-dopa), trial design, origin and preparation of donor cells, immunosuppression, and surgical techniques for successful functional outcome and avoiding unwanted side effects. Hopefully, the TRANSEURO project will provide some of this essential knowledge and as such contribute to the development of a standardized, efficient and safe protocol that can serve as a template for clinical trials, including expected future stem cell-based trials for PD. However, before such a stem cell therapy can be initiated, also a number fundamental biological issues need to be taken into consideration. Embryonic stem cells (ESCs) and the newly developed induced pluripotent stem (iPS) cells seem to have the greatest potential to generate large numbers of dopaminergic neurons, but the use of these cell types is associated with a risk of tumor formation due to potentially remaining undifferentiated cells in the donor cell preparations. Moreover, using ESCs are related to ethical and immunological concerns. IPS cells and mesenchymal stem cells have the prospect of being made patient specific overcoming the risk of immune rejection, and they are not affiliated with ethical problems. So far it has been difficult to generate large numbers of dopaminergic neurons from neural stem cells, but these cells have a more straightforward differentiation pathway to form midbrain specific dopaminergic neurons, and they are not tumorigenic. Independent of the type of stem cell in question, it will be challenging to develop a differentiation protocol leading to "truly" functional dopaminergic projection neurons with midbrain characteristics without still having undifferentiated cells in the preparation.

\section{Abbreviations}

BDNF, brain-derived neurotrophic factor; DBS, Deep brain stimulation; ESC, embryonic stem cell; FACS, Fluorescence-activated cell sorting; FGF, fibroblast growth factor; GDNF, glial-derived neurotrophic factor; 6-OHDA, 6-hydroxydopamine; iPS, induced pluripotent stem cell; MPTP, 1-methyl-4-phenyl-1,2,3,6-tetrahydropyridine; MSC, mesenchymal stem cell; NSC, neural stem cell; SDIA, stromal cell-derived inducing activity; PD, Parkinson's disease, PET; Positron Emmision Tomography; Shh, sonic hedgehog; SVZ, subventricular zone; TGF, transforming growth factor; UPDRS, unified Parkinson's disease rating scale.

\section{References}

Ahn, Y. H., J. C. Bensadoun, P. Aebischer, A. D. Zurn, A. Seiger, A. Bjorklund, O. Lindvall, L. Wahlberg, P. Brundin, and G. S. Kaminski Schierle. 2005. Increased fiber outgrowth from xeno-transplanted human embryonic dopaminergic neurons with co-implants of polymer-encapsulated genetically modified cells releasing glial cell line-derived neurotrophic factor. Brain Res Bull 66 (2):135-42.

Akerud, P., J. M. Canals, E. Y. Snyder, and E. Arenas. 2001. Neuroprotection through delivery of glial cell line-derived neurotrophic factor by neural stem cells in a mouse model of Parkinson's disease. J Neurosci 21 (20):8108-18. 
Allen, G. S., R. S. Burns, N. B. Tulipan, and R. A. Parker. 1989. Adrenal medullary transplantation to the caudate nucleus in Parkinson's disease. Initial clinical results in 18 patients. Arch Neurol 46 (5):487-91.

Altman, J., and G. D. Das. 1965. Autoradiographic and histological evidence of postnatal hippocampal neurogenesis in rats. J Comp Neurol 124 (3):319-35.

Andersson, E. K., D. K. Irvin, J. Ahlsio, and M. Parmar. 2007. Ngn2 and Nurr1 act in synergy to induce midbrain dopaminergic neurons from expanded neural stem and progenitor cells. Exp Cell Res 313 (6):1172-80.

Arjona, V., A. Minguez-Castellanos, R. J. Montoro, A. Ortega, F. Escamilla, J. J. Toledo-Aral, R. Pardal, S. Mendez-Ferrer, J. M. Martin, M. Perez, M. J. Katati, E. Valencia, T. Garcia, and J. Lopez-Barneo. 2003. Autotransplantation of human carotid body cell aggregates for treatment of Parkinson's disease. Neurosurgery 53 (2):321-8; discussion 328-30.

Azizi, S. A., D. Stokes, B. J. Augelli, C. DiGirolamo, and D. J. Prockop. 1998. Engraftment and migration of human bone marrow stromal cells implanted in the brains of albino rats--similarities to astrocyte grafts. Proc Natl Acad Sci U S A 95 (7):3908-13.

Backlund, E. O., P. O. Granberg, B. Hamberger, E. Knutsson, A. Martensson, G. Sedvall, A. Seiger, and L. Olson. 1985. Transplantation of adrenal medullary tissue to striatum in parkinsonism. First clinical trials. J Neurosurg 62 (2):169-73.

Baquet, Z. C., P. C. Bickford, and K. R. Jones. 2005. Brain-derived neurotrophic factor is required for the establishment of the proper number of dopaminergic neurons in the substantia nigra pars compacta. J Neurosci 25 (26):6251-9.

Barberi, T., P. Klivenyi, N. Y. Calingasan, H. Lee, H. Kawamata, K. Loonam, A. L. Perrier, J. Bruses, M. E. Rubio, N. Topf, V. Tabar, N. L. Harrison, M. F. Beal, M. A. Moore, and L. Studer. 2003. Neural subtype specification of fertilization and nuclear transfer embryonic stem cells and application in parkinsonian mice. Nat Biotechnol 21 (10):1200-7.

Barzilay, R., I. Kan, T. Ben-Zur, S. Bulvik, E. Melamed, and D. Offen. 2008. Induction of human mesenchymal stem cells into dopamine-producing cells with different differentiation protocols. Stem Cells Dev 17 (3):547-54.

Bayer, S. A., J. W. Yackel, and P. S. Puri. 1982. Neurons in the rat dentate gyrus granular layer substantially increase during juvenile and adult life. Science 216 (4548):890-2.

Behrstock, S., A. Ebert, J. McHugh, S. Vosberg, J. Moore, B. Schneider, E. Capowski, D. Hei, J. Kordower, P. Aebischer, and C. N. Svendsen. 2006. Human neural progenitors deliver glial cell line-derived neurotrophic factor to parkinsonian rodents and aged primates. Gene Ther 13 (5):379-88.

Ben-Hur, T., M. Idelson, H. Khaner, M. Pera, E. Reinhartz, A. Itzik, and B. E. Reubinoff. 2004. Transplantation of human embryonic stem cell-derived neural progenitors improves behavioral deficit in Parkinsonian rats. Stem Cells 22 (7):1246-55.

Beresford, J. N., J. H. Bennett, C. Devlin, P. S. Leboy, and M. E. Owen. 1992. Evidence for an inverse relationship between the differentiation of adipocytic and osteogenic cells in rat marrow stromal cell cultures. J Cell Sci 102 ( Pt 2):341-51.

Bianchi, G., A. Muraglia, A. Daga, G. Corte, R. Cancedda, and R. Quarto. 2001. Microenvironment and stem properties of bone marrow-derived mesenchymal cells. Wound Repair Regen 9 (6):460-6. 
Bjorklund, A., S. B. Dunnett, P. Brundin, A. J. Stoessl, C. R. Freed, R. E. Breeze, M. Levivier, M. Peschanski, L. Studer, and R. Barker. 2003. Neural transplantation for the treatment of Parkinson's disease. Lancet Neurol 2 (7):437-45.

Bjorklund, A., and U. Stenevi. 1979. Reconstruction of the nigrostriatal dopamine pathway by intracerebral nigral transplants. Brain Res 177 (3):555-60.

Bjorklund, L. M., R. Sanchez-Pernaute, S. Chung, T. Andersson, I. Y. Chen, K. S. McNaught, A. L. Brownell, B. G. Jenkins, C. Wahlestedt, K. S. Kim, and O. Isacson. 2002. Embryonic stem cells develop into functional dopaminergic neurons after transplantation in a Parkinson rat model. Proc Natl Acad Sci U S A 99 (4):2344-9.

Black, I. B., and D. Woodbury. 2001. Adult rat and human bone marrow stromal stem cells differentiate into neurons. Blood Cells Mol Dis 27 (3):632-6.

Blondheim, N. R., Y. S. Levy, T. Ben-Zur, A. Burshtein, T. Cherlow, I. Kan, R. Barzilai, M. Bahat-Stromza, Y. Barhum, S. Bulvik, E. Melamed, and D. Offen. 2006. Human mesenchymal stem cells express neural genes, suggesting a neural predisposition. Stem Cells Dev 15 (2):141-64.

Brevig, T., M. Meyer, T. Kristensen, J. Zimmer, and J. Holgersson. 2001. Xenotransplantation for brain repair: reduction of porcine donor tissue immunogenicity by treatment with anti-Gal antibodies and complement. Transplantation 72 (2):190-6.

Brundin, P., O. G. Nilsson, R. E. Strecker, O. Lindvall, B. Astedt, and A. Bjorklund. 1986. Behavioural effects of human fetal dopamine neurons grafted in a rat model of Parkinson's disease. Exp Brain Res 65 (1):235-40.

Brundin, P., O. Pogarell, P. Hagell, P. Piccini, H. Widner, A. Schrag, A. Kupsch, L. Crabb, P. Odin, B. Gustavii, A. Bjorklund, D. J. Brooks, C. D. Marsden, W. H. Oertel, N. P. Quinn, S. Rehncrona, and O. Lindvall. 2000. Bilateral caudate and putamen grafts of embryonic mesencephalic tissue treated with lazaroids in Parkinson's disease. Brain 123 ( Pt 7):1380-90.

Cai, J., M. Yang, E. Poremsky, S. Kidd, J. S. Schneider, and L. Iacovitti. 2010. Dopaminergic neurons derived from human induced pluripotent stem cells survive and integrate into 6-OHDA-lesioned rats. Stem Cells Dev 19 (7):1017-23.

Carlsson, A., M. Lindqvist, and T. Magnusson. 1957. 3,4-Dihydroxyphenylalanine and 5hydroxytryptophan as reserpine antagonists. Nature 180 (4596):1200.

Carlsson, T., M. Carta, C. Winkler, A. Bjorklund, and D. Kirik. 2007. Serotonin neuron transplants exacerbate L-DOPA-induced dyskinesias in a rat model of Parkinson's disease. J Neurosci 27 (30):8011-22.

Carpenter, M. K., M. S. Inokuma, J. Denham, T. Mujtaba, C. P. Chiu, and M. S. Rao. 2001. Enrichment of neurons and neural precursors from human embryonic stem cells. Exp Neurol 172 (2):383-97.

Carta, M., T. Carlsson, D. Kirik, and A. Bjorklund. 2007. Dopamine released from 5-HT terminals is the cause of L-DOPA-induced dyskinesia in parkinsonian rats. Brain 130 (Pt 7):1819-33.

Carvey, P. M., Z. D. Ling, C. E. Sortwell, M. R. Pitzer, S. O. McGuire, A. Storch, and T. J. Collier. 2001. A clonal line of mesencephalic progenitor cells converted to dopamine neurons by hematopoietic cytokines: a source of cells for transplantation in Parkinson's disease. Exp Neurol 171 (1):98-108.

Chin, M. H., M. J. Mason, W. Xie, S. Volinia, M. Singer, C. Peterson, G. Ambartsumyan, O. Aimiuwu, L. Richter, J. Zhang, I. Khvorostov, V. Ott, M. Grunstein, N. Lavon, N. Benvenisty, C. M. Croce, A. T. Clark, T. Baxter, A. D. Pyle, M. A. Teitell, M. 
Pelegrini, K. Plath, and W. E. Lowry. 2009. Induced pluripotent stem cells and embryonic stem cells are distinguished by gene expression signatures. Cell Stem Cell $5(1): 111-23$.

Christophersen, N. S., X. Meijer, J. R. Jorgensen, U. Englund, M. Gronborg, A. Seiger, P. Brundin, and L. U. Wahlberg. 2006. Induction of dopaminergic neurons from growth factor expanded neural stem/progenitor cell cultures derived from human first trimester forebrain. Brain Res Bull 70 (4-6):457-66.

Chung, S., E. Hedlund, M. Hwang, D. W. Kim, B. S. Shin, D. Y. Hwang, U. Jung Kang, O. Isacson, and K. S. Kim. 2005. The homeodomain transcription factor Pitx3 facilitates differentiation of mouse embryonic stem cells into AHD2-expressing dopaminergic neurons. Mol Cell Neurosci 28 (2):241-52.

Chung, S., B. S. Shin, E. Hedlund, J. Pruszak, A. Ferree, U. J. Kang, O. Isacson, and K. S. Kim. 2006. Genetic selection of sox1GFP-expressing neural precursors removes residual tumorigenic pluripotent stem cells and attenuates tumor formation after transplantation. J Neurochem 97 (5):1467-80.

Chung, S., K. C. Sonntag, T. Andersson, L. M. Bjorklund, J. J. Park, D. W. Kim, U. J. Kang, O. Isacson, and K. S. Kim. 2002. Genetic engineering of mouse embryonic stem cells by Nurr1 enhances differentiation and maturation into dopaminergic neurons. Eur J Neurosci 16 (10):1829-38.

Cooper, O., and O. Isacson. 2004. Intrastriatal transforming growth factor alpha delivery to a model of Parkinson's disease induces proliferation and migration of endogenous adult neural progenitor cells without differentiation into dopaminergic neurons. $J$ Neurosci 24 (41):8924-31.

Cowan, C. A., J. Atienza, D. A. Melton, and K. Eggan. 2005. Nuclear reprogramming of somatic cells after fusion with human embryonic stem cells. Science 309 (5739):136973.

Curtis, M. A., M. Kam, U. Nannmark, M. F. Anderson, M. Z. Axell, C. Wikkelso, S. Holtas, W. M. van Roon-Mom, T. Bjork-Eriksson, C. Nordborg, J. Frisen, M. Dragunow, R. L. Faull, and P. S. Eriksson. 2007. Human neuroblasts migrate to the olfactory bulb via a lateral ventricular extension. Science 315 (5816):1243-9.

de Chevigny, A., O. Cooper, A. Vinuela, C. Reske-Nielsen, D. C. Lagace, A. J. Eisch, and O. Isacson. 2008. Fate mapping and lineage analyses demonstrate the production of a large number of striatal neuroblasts after transforming growth factor alpha and noggin striatal infusions into the dopamine-depleted striatum. Stem Cells 26 (9):2349-60.

Deacon, T., J. Schumacher, J. Dinsmore, C. Thomas, P. Palmer, S. Kott, A. Edge, D. Penney, S. Kassissieh, P. Dempsey, and O. Isacson. 1997. Histological evidence of fetal pig neural cell survival after transplantation into a patient with Parkinson's disease. Nat Med 3 (3):350-3.

Deng, J., R. Shoemaker, B. Xie, A. Gore, E. M. LeProust, J. Antosiewicz-Bourget, D. Egli, N. Maherali, I. H. Park, J. Yu, G. Q. Daley, K. Eggan, K. Hochedlinger, J. Thomson, W. Wang, Y. Gao, and K. Zhang. 2009. Targeted bisulfite sequencing reveals changes in DNA methylation associated with nuclear reprogramming. Nat Biotechnol 27 (4):353-60.

Deng, W., M. Obrocka, I. Fischer, and D. J. Prockop. 2001. In vitro differentiation of human marrow stromal cells into early progenitors of neural cells by conditions that increase intracellular cyclic AMP. Biochem Biophys Res Commun 282 (1):148-52. 
Dezawa, M., H. Kanno, M. Hoshino, H. Cho, N. Matsumoto, Y. Itokazu, N. Tajima, H. Yamada, H. Sawada, H. Ishikawa, T. Mimura, M. Kitada, Y. Suzuki, and C. Ide. 2004. Specific induction of neuronal cells from bone marrow stromal cells and application for autologous transplantation. J Clin Invest 113 (12):1701-10.

Draper, J. S., K. Smith, P. Gokhale, H. D. Moore, E. Maltby, J. Johnson, L. Meisner, T. P. Zwaka, J. A. Thomson, and P. W. Andrews. 2004. Recurrent gain of chromosomes 17q and 12 in cultured human embryonic stem cells. Nat Biotechnol 22 (1):53-4.

Drucker-Colin, R., I. Madrazo, F. Ostrosky-Solis, M. Shkurovich, R. Franco, and C. Torres. 1988. Adrenal medullary tissue transplants in the caudate nucleus of Parkinson's patients. Prog Brain Res 78:567-74.

Dunnett, S. B., A. Bjorklund, R. H. Schmidt, U. Stenevi, and S. D. Iversen. 1983. Intracerebral grafting of neuronal cell suspensions. IV. Behavioural recovery in rats with unilateral 6-OHDA lesions following implantation of nigral cell suspensions in different forebrain sites. Acta Physiol Scand Suppl 522:29-37.

Dunnett, S. B., A. Bjorklund, U. Stenevi, and S. D. Iversen. 1981. Behavioural recovery following transplantation of substantia nigra in rats subjected to 6-OHDA lesions of the nigrostriatal pathway. II. Bilateral lesions. Brain Res 229 (2):457-70.

Dziewczapolski, G., D. C. Lie, J. Ray, F. H. Gage, and C. W. Shults. 2003. Survival and differentiation of adult rat-derived neural progenitor cells transplanted to the striatum of hemiparkinsonian rats. Exp Neurol 183 (2):653-64.

Espejo, E. F., R. J. Montoro, J. A. Armengol, and J. Lopez-Barneo. 1998. Cellular and functional recovery of Parkinsonian rats after intrastriatal transplantation of carotid body cell aggregates. Neuron 20 (2):197-206.

Evans, J. R., and R. A. Barker. 2008. Neurotrophic factors as a therapeutic target for Parkinson's disease. Expert Opin Ther Targets 12 (4):437-47.

Fahn, S. 2006. Levodopa in the treatment of Parkinson's disease. J Neural Transm Suppl (71):115.

Freed, C. R., R. E. Breeze, N. L. Rosenberg, S. A. Schneck, E. Kriek, J. X. Qi, T. Lone, Y. B. Zhang, J. A. Snyder, T. H. Wells, and et al. 1992. Survival of implanted fetal dopamine cells and neurologic improvement 12 to 46 months after transplantation for Parkinson's disease. N Engl J Med 327 (22):1549-55.

Freed, C. R., R. E. Breeze, N. L. Rosenberg, S. A. Schneck, T. H. Wells, J. N. Barrett, S. T. Grafton, S. C. Huang, D. Eidelberg, and D. A. Rottenberg. 1990. Transplantation of human fetal dopamine cells for Parkinson's disease. Results at 1 year. Arch Neurol 47 (5):505-12.

Freed, C. R., R. E. Breeze, N. L. Rosenberg, S. A. Schneck, T. H. Wells, J. N. Barrett, S. T. Grafton, J. C. Mazziotta, D. Eidelberg, and D. A. Rottenberg. 1990. Therapeutic effects of human fetal dopamine cells transplanted in a patient with Parkinson's disease. Prog Brain Res 82:715-21.

Freed, C. R., P. E. Greene, R. E. Breeze, W. Y. Tsai, W. DuMouchel, R. Kao, S. Dillon, H. Winfield, S. Culver, J. Q. Trojanowski, D. Eidelberg, and S. Fahn. 2001. Transplantation of embryonic dopamine neurons for severe Parkinson's disease. $N$ Engl J Med 344 (10):710-9.

Freed, W. J., M. Poltorak, and J. B. Becker. 1990. Intracerebral adrenal medulla grafts: a review. Exp Neurol 110 (2):139-66.

Freund, T. F., J. P. Bolam, A. Bjorklund, U. Stenevi, S. B. Dunnett, J. F. Powell, and A. D. Smith. 1985. Efferent synaptic connections of grafted dopaminergic neurons 
reinnervating the host neostriatum: a tyrosine hydroxylase immunocytochemical study. J Neurosci 5 (3):603-16.

Frielingsdorf, H., K. Schwarz, P. Brundin, and P. Mohapel. 2004. No evidence for new dopaminergic neurons in the adult mammalian substantia nigra. Proc Natl Acad Sci U S A 101 (27):10177-82.

Friling, S., E. Andersson, L. H. Thompson, M. E. Jonsson, J. B. Hebsgaard, E. Nanou, Z. Alekseenko, U. Marklund, S. Kjellander, N. Volakakis, O. Hovatta, A. El Manira, A. Bjorklund, T. Perlmann, and J. Ericson. 2009. Efficient production of mesencephalic dopamine neurons by Lmx1a expression in embryonic stem cells. Proc Natl Acad Sci U S A 106 (18):7613-8.

Galpern, W. R., L. H. Burns, T. W. Deacon, J. Dinsmore, and O. Isacson. 1996. Xenotransplantation of porcine fetal ventral mesencephalon in a rat model of Parkinson's disease: functional recovery and graft morphology. Exp Neurol 140 (1):1-13.

Goetz, C. G., G. T. Stebbins, 3rd, H. L. Klawans, W. C. Koller, R. G. Grossman, R. A. Bakay, and R. D. Penn. 1991. United Parkinson Foundation Neurotransplantation Registry on adrenal medullary transplants: presurgical, and 1- and 2-year follow-up. Neurology 41 (11):1719-22.

Hargus, G., O. Cooper, M. Deleidi, A. Levy, K. Lee, E. Marlow, A. Yow, F. Soldner, D. Hockemeyer, P. J. Hallett, T. Osborn, R. Jaenisch, and O. Isacson. 2010. Differentiated Parkinson patient-derived induced pluripotent stem cells grow in the adult rodent brain and reduce motor asymmetry in Parkinsonian rats. Proc Natl Acad Sci U S A 107 (36):15921-6.

Hauser, R. A., and T. A. Zesiewicz. 2007. Advances in the pharmacologic management of early Parkinson disease. Neurologist 13 (3):126-32.

Head, J. R., and W. S. Griffin. 1985. Functional capacity of solid tissue transplants in the brain: evidence for immunological privilege. Proc $R$ Soc Lond B Biol Sci 224 (1236):375-87.

Hedlund, E., J. Pruszak, T. Lardaro, W. Ludwig, A. Vinuela, K. S. Kim, and O. Isacson. 2008. Embryonic stem cell-derived Pitx3-enhanced green fluorescent protein midbrain dopamine neurons survive enrichment by fluorescence-activated cell sorting and function in an animal model of Parkinson's disease. Stem Cells 26 (6):1526-36.

Hermann, A., M. Maisel, and A. Storch. 2006. Epigenetic conversion of human adult bone mesodermal stromal cells into neuroectodermal cell types for replacement therapy of neurodegenerative disorders. Expert Opin Biol Ther 6 (7):653-70.

Hermann, A., M. Maisel, F. Wegner, S. Liebau, D. W. Kim, M. Gerlach, J. Schwarz, K. S. Kim, and A. Storch. 2006. Multipotent neural stem cells from the adult tegmentum with dopaminergic potential develop essential properties of functional neurons. Stem Cells 24 (4):949-64.

Hitoshi, S., V. Tropepe, M. Ekker, and D. van der Kooy. 2002. Neural stem cell lineages are regionally specified, but not committed, within distinct compartments of the developing brain. Development 129 (1):233-44.

Holden, C. 2009. Neuroscience. Fetal cells again? Science 326 (5951):358-9.

Horiguchi, S., J. Takahashi, Y. Kishi, A. Morizane, Y. Okamoto, M. Koyanagi, M. Tsuji, K. Tashiro, T. Honjo, S. Fujii, and N. Hashimoto. 2004. Neural precursor cells derived from human embryonic brain retain regional specificity. J Neurosci Res 75 (6):817-24. 
Hudson, J. L., A. Hoffman, I. Stromberg, B. J. Hoffer, and J. W. Moorhead. 1994. Allogeneic grafts of fetal dopamine neurons: behavioral indices of immunological interactions. Neurosci Lett 171 (1-2):32-6.

Huffaker, T. K., B. D. Boss, A. S. Morgan, N. T. Neff, R. E. Strecker, M. S. Spence, and R. Miao. 1989. Xenografting of fetal pig ventral mesencephalon corrects motor asymmetry in the rat model of Parkinson's disease. Exp Brain Res 77 (2):329-36.

Hurtig, H., J. Joyce, J. R. Sladek, Jr., and J. Q. Trojanowski. 1989. Postmortem analysis of adrenal-medulla-to-caudate autograft in a patient with Parkinson's disease. Ann Neurol 25 (6):607-14.

Iacovitti, L., A. E. Donaldson, C. E. Marshall, S. Suon, and M. Yang. 2007. A protocol for the differentiation of human embryonic stem cells into dopaminergic neurons using only chemically defined human additives: Studies in vitro and in vivo. Brain Res 1127 (1):19-25.

Inden, M., D. Kim, Y. Gu, Y. Kitamura, J. Kondo, D. Tsuchiya, T. Taniguchi, S. Shimohama, A. Akaike, S. Sumi, and K. Inoue. 2004. Pharmacological characteristics of rotational behavior in hemiparkinsonian rats transplanted with mouse embryonic stem cell-derived neurons. J Pharmacol Sci 96 (1):53-64.

Itakura, T., Y. Uematsu, N. Nakao, E. Nakai, and K. Nakai. 1997. Transplantation of autologous sympathetic ganglion into the brain with Parkinson's disease. Longterm follow-up of 35 cases. Stereotact Funct Neurosurg 69 (1-4 Pt 2):112-5.

Jiang, Y., D. Henderson, M. Blackstad, A. Chen, R. F. Miller, and C. M. Verfaillie. 2003. Neuroectodermal differentiation from mouse multipotent adult progenitor cells. Proc Natl Acad Sci U S A 100 Suppl 1:11854-60.

Kaji, K., K. Norrby, A. Paca, M. Mileikovsky, P. Mohseni, and K. Woltjen. 2009. Virus-free induction of pluripotency and subsequent excision of reprogramming factors. Nature 458 (7239):771-5.

Kawasaki, H., K. Mizuseki, S. Nishikawa, S. Kaneko, Y. Kuwana, S. Nakanishi, S. I. Nishikawa, and Y. Sasai. 2000. Induction of midbrain dopaminergic neurons from ES cells by stromal cell-derived inducing activity. Neuron 28 (1):31-40.

Kim, D., C. H. Kim, J. I. Moon, Y. G. Chung, M. Y. Chang, B. S. Han, S. Ko, E. Yang, K. Y. Cha, R. Lanza, and K. S. Kim. 2009. Generation of human induced pluripotent stem cells by direct delivery of reprogramming proteins. Cell Stem Cell 4 (6):472-6.

Kim, H. J., M. Sugimori, M. Nakafuku, and C. N. Svendsen. 2007. Control of neurogenesis and tyrosine hydroxylase expression in neural progenitor cells through bHLH proteins and Nurr1. Exp Neurol 203 (2):394-405.

Kim, J. H., J. M. Auerbach, J. A. Rodriguez-Gomez, I. Velasco, D. Gavin, N. Lumelsky, S. H. Lee, J. Nguyen, R. Sanchez-Pernaute, K. Bankiewicz, and R. McKay. 2002. Dopamine neurons derived from embryonic stem cells function in an animal model of Parkinson's disease. Nature 418 (6893):50-6.

Kishima, H., T. Poyot, J. Bloch, J. Dauguet, F. Conde, F. Dolle, F. Hinnen, W. Pralong, S. Palfi, N. Deglon, P. Aebischer, and P. Hantraye. 2004. Encapsulated GDNFproducing $\mathrm{C} 2 \mathrm{C} 12$ cells for Parkinson's disease: a pre-clinical study in chronic MPTP-treated baboons. Neurobiol Dis 16 (2):428-39.

Kohyama, J., H. Abe, T. Shimazaki, A. Koizumi, K. Nakashima, S. Gojo, T. Taga, H. Okano, J. Hata, and A. Umezawa. 2001. Brain from bone: efficient "meta-differentiation" of marrow stroma-derived mature osteoblasts to neurons with Noggin or a demethylating agent. Differentiation 68 (4-5):235-44. 
Kompoliti, K., Y. Chu, K. M. Shannon, and J. H. Kordower. 2007. Neuropathological study 16 years after autologous adrenal medullary transplantation in a Parkinson's disease patient. Mov Disord 22 (11):1630-3.

Kopen, G. C., D. J. Prockop, and D. G. Phinney. 1999. Marrow stromal cells migrate throughout forebrain and cerebellum, and they differentiate into astrocytes after injection into neonatal mouse brains. Proc Natl Acad Sci U S A 96 (19):10711-6.

Kordower, J. H., Y. Chu, R. A. Hauser, T. B. Freeman, and C. W. Olanow. 2008. Lewy bodylike pathology in long-term embryonic nigral transplants in Parkinson's disease. Nat Med 14 (5):504-6.

Kordower, J. H., E. Cochran, R. D. Penn, and C. G. Goetz. 1991. Putative chromaffin cell survival and enhanced host-derived TH-fiber innervation following a functional adrenal medulla autograft for Parkinson's disease. Ann Neurol 29 (4):405-12.

Kordower, J. H., T. B. Freeman, B. J. Snow, F. J. Vingerhoets, E. J. Mufson, P. R. Sanberg, R. A. Hauser, D. A. Smith, G. M. Nauert, D. P. Perl, and et al. 1995. Neuropathological evidence of graft survival and striatal reinnervation after the transplantation of fetal mesencephalic tissue in a patient with Parkinson's disease. N Engl J Med 332 (17):1118-24.

Kordower, J. H., J. M. Rosenstein, T. J. Collier, M. A. Burke, E. Y. Chen, J. M. Li, L. Martel, A. E. Levey, E. J. Mufson, T. B. Freeman, and C. W. Olanow. 1996. Functional fetal nigral grafts in a patient with Parkinson's disease: chemoanatomic, ultrastructural, and metabolic studies. J Comp Neurol 370 (2):203-30.

Krabbe, C., E. Courtois, P. Jensen, J. R. Jorgensen, J. Zimmer, A. Martinez-Serrano, and M. Meyer. 2009. Enhanced dopaminergic differentiation of human neural stem cells by synergistic effect of Bcl-xL and reduced oxygen tension. J Neurochem 110 (6):190820.

Krabbe, C., J. Zimmer, and M. Meyer. 2005. Neural transdifferentiation of mesenchymal stem cells--a critical review. APMIS 113 (11-12):831-44.

Lane, E. L., C. Winkler, P. Brundin, and M. A. Cenci. 2006. The impact of graft size on the development of dyskinesia following intrastriatal grafting of embryonic dopamine neurons in the rat. Neurobiol Dis 22 (2):334-45.

Lee, S. H., N. Lumelsky, L. Studer, J. M. Auerbach, and R. D. McKay. 2000. Efficient generation of midbrain and hindbrain neurons from mouse embryonic stem cells. Nat Biotechnol 18 (6):675-9.

Levy, Y. S., Y. Gilgun-Sherki, E. Melamed, and D. Offen. 2005. Therapeutic potential of neurotrophic factors in neurodegenerative diseases. BioDrugs 19 (2):97-127.

Li, J. Y., E. Englund, J. L. Holton, D. Soulet, P. Hagell, A. J. Lees, T. Lashley, N. P. Quinn, S. Rehncrona, A. Bjorklund, H. Widner, T. Revesz, O. Lindvall, and P. Brundin. 2008. Lewy bodies in grafted neurons in subjects with Parkinson's disease suggest hostto-graft disease propagation. Nat Med 14 (5):501-3.

Lie, D. C., G. Dziewczapolski, A. R. Willhoite, B. K. Kaspar, C. W. Shults, and F. H. Gage. 2002. The adult substantia nigra contains progenitor cells with neurogenic potential. J Neurosci 22 (15):6639-49.

Lindvall, O., E. O. Backlund, L. Farde, G. Sedvall, R. Freedman, B. Hoffer, A. Nobin, A. Seiger, and L. Olson. 1987. Transplantation in Parkinson's disease: two cases of adrenal medullary grafts to the putamen. Ann Neurol 22 (4):457-68.

Lindvall, O., P. Brundin, H. Widner, S. Rehncrona, B. Gustavii, R. Frackowiak, K. L. Leenders, G. Sawle, J. C. Rothwell, C. D. Marsden, and et al. 1990. Grafts of fetal 
dopamine neurons survive and improve motor function in Parkinson's disease. Science 247 (4942):574-7.

Lindvall, O., S. Rehncrona, P. Brundin, B. Gustavii, B. Astedt, H. Widner, T. Lindholm, A. Bjorklund, K. L. Leenders, J. C. Rothwell, R. Frackowiak, D. Marsden, B. Johnels, G. Steg, R. Freedman, B. J. Hoffer, A. Seiger, M. Bygdeman, I. Stromberg, and L. Olson. 1989. Human fetal dopamine neurons grafted into the striatum in two patients with severe Parkinson's disease. A detailed account of methodology and a 6-month follow-up. Arch Neurol 46 (6):615-31.

Lindvall, O., G. Sawle, H. Widner, J. C. Rothwell, A. Bjorklund, D. Brooks, P. Brundin, R. Frackowiak, C. D. Marsden, P. Odin, and et al. 1994. Evidence for long-term survival and function of dopaminergic grafts in progressive Parkinson's disease. Ann Neurol 35 (2):172-80.

Liste, I., E. Garcia-Garcia, and A. Martinez-Serrano. 2004. The generation of dopaminergic neurons by human neural stem cells is enhanced by Bcl-XL, both in vitro and in vivo. J Neurosci 24 (48):10786-95.

Liu, W. G., G. Q. Lu, B. Li, and S. D. Chen. 2007. Dopaminergic neuroprotection by neurturin-expressing c17.2 neural stem cells in a rat model of Parkinson's disease. Parkinsonism Relat Disord 13 (2):77-88.

Lohle, M., and H. Reichmann. 2010. Clinical neuroprotection in Parkinson's disease - still waiting for the breakthrough. J Neurol Sci 289 (1-2):104-14.

Lois, C., and A. Alvarez-Buylla. 1994. Long-distance neuronal migration in the adult mammalian brain. Science 264 (5162):1145-8.

Lotharius, J., S. Barg, P. Wiekop, C. Lundberg, H. K. Raymon, and P. Brundin. 2002. Effect of mutant alpha-synuclein on dopamine homeostasis in a new human mesencephalic cell line. J Biol Chem 277 (41):38884-94.

Lu, P., A. Blesch, and M. H. Tuszynski. 2004. Induction of bone marrow stromal cells to neurons: differentiation, transdifferentiation, or artifact? J Neurosci Res 77 (2):174-91.

Luquin, M. R., R. J. Montoro, J. Guillen, L. Saldise, R. Insausti, J. Del Rio, and J. LopezBarneo. 1999. Recovery of chronic parkinsonian monkeys by autotransplants of carotid body cell aggregates into putamen. Neuron 22 (4):743-50.

Ma, Y., A. Feigin, V. Dhawan, M. Fukuda, Q. Shi, P. Greene, R. Breeze, S. Fahn, C. Freed, and D. Eidelberg. 2002. Dyskinesia after fetal cell transplantation for parkinsonism: a PET study. Ann Neurol 52 (5):628-34.

Madrazo, I., R. Franco-Bourland, F. Ostrosky-Solis, M. Aguilera, C. Cuevas, F. Alvarez, E. Magallon, C. Zamorano, and A. Morelos. 1990. Neural transplantation (autoadrenal, fetal nigral and fetal adrenal) in Parkinson's disease: the Mexican experience. Prog Brain Res 82:593-602.

Maherali, N., R. Sridharan, W. Xie, J. Utikal, S. Eminli, K. Arnold, M. Stadtfeld, R. Yachechko, J. Tchieu, R. Jaenisch, K. Plath, and K. Hochedlinger. 2007. Directly reprogrammed fibroblasts show global epigenetic remodeling and widespread tissue contribution. Cell Stem Cell 1 (1):55-70.

Maitra, A., D. E. Arking, N. Shivapurkar, M. Ikeda, V. Stastny, K. Kassauei, G. Sui, D. J. Cutler, Y. Liu, S. N. Brimble, K. Noaksson, J. Hyllner, T. C. Schulz, X. Zeng, W. J. Freed, J. Crook, S. Abraham, A. Colman, P. Sartipy, S. Matsui, M. Carpenter, A. F. Gazdar, M. Rao, and A. Chakravarti. 2005. Genomic alterations in cultured human embryonic stem cells. Nat Genet 37 (10):1099-103. 
Markakis, E. A., T. D. Palmer, L. Randolph-Moore, P. Rakic, and F. H. Gage. 2004. Novel neuronal phenotypes from neural progenitor cells. J Neurosci 24 (12):2886-97.

Masip, M., A. Veiga, J. C. Izpisua Belmonte, and C. Simon. 2010. Reprogramming with defined factors: from induced pluripotency to induced transdifferentiation. Mol Hum Reprod 16 (11):856-68.

Meissner, A., M. Wernig, and R. Jaenisch. 2007. Direct reprogramming of genetically unmodified fibroblasts into pluripotent stem cells. Nat Biotechnol 25 (10):1177-81.

Mendez, I., R. Sanchez-Pernaute, O. Cooper, A. Vinuela, D. Ferrari, L. Bjorklund, A. Dagher, and O. Isacson. 2005. Cell type analysis of functional fetal dopamine cell suspension transplants in the striatum and substantia nigra of patients with Parkinson's disease. Brain 128 (Pt 7):1498-510.

Mendez, I., A. Vinuela, A. Astradsson, K. Mukhida, P. Hallett, H. Robertson, T. Tierney, R. Holness, A. Dagher, J. Q. Trojanowski, and O. Isacson. 2008. Dopamine neurons implanted into people with Parkinson's disease survive without pathology for 14 years. Nat Med 14 (5):507-9.

Morizane, A., J. Takahashi, M. Shinoyama, M. Ideguchi, Y. Takagi, H. Fukuda, M. Koyanagi, Y. Sasai, and N. Hashimoto. 2006. Generation of graftable dopaminergic neuron progenitors from mouse ES cells by a combination of coculture and neurosphere methods. J Neurosci Res 83 (6):1015-27.

Morley, J. F., and H. I. Hurtig. 2010. Current understanding and management of Parkinson disease: five new things. Neurology 75 (18 Suppl 1):S9-15.

Morshead, C. M., B. A. Reynolds, C. G. Craig, M. W. McBurney, W. A. Staines, D. Morassutti, S. Weiss, and D. van der Kooy. 1994. Neural stem cells in the adult mammalian forebrain: a relatively quiescent subpopulation of subependymal cells. Neuron 13 (5):1071-82.

Munoz-Elias, G., D. Woodbury, and I. B. Black. 2003. Marrow stromal cells, mitosis, and neuronal differentiation: stem cell and precursor functions. Stem Cells 21 (4):437-48.

Nakagawa, M., M. Koyanagi, K. Tanabe, K. Takahashi, T. Ichisaka, T. Aoi, K. Okita, Y. Mochiduki, N. Takizawa, and S. Yamanaka. 2008. Generation of induced pluripotent stem cells without Myc from mouse and human fibroblasts. Nat Biotechnol 26 (1):101-6.

Nakao, N., K. Kakishita, Y. Uematsu, T. Yoshimasu, T. Bessho, K. Nakai, Y. Naito, and T. Itakura. 2001. Enhancement of the response to levodopa therapy after intrastriatal transplantation of autologous sympathetic neurons in patients with Parkinson disease. J Neurosurg 95 (2):275-84.

Nakao, N., A. Shintani-Mizushima, K. Kakishita, and T. Itakura. 2004. The ability of grafted human sympathetic neurons to synthesize and store dopamine: a potential mechanism for the clinical effect of sympathetic neuron autografts in patients with Parkinson's disease. Exp Neurol 188 (1):65-73.

Neuhuber, B., G. Gallo, L. Howard, L. Kostura, A. Mackay, and I. Fischer. 2004. Reevaluation of in vitro differentiation protocols for bone marrow stromal cells: disruption of actin cytoskeleton induces rapid morphological changes and mimics neuronal phenotype. J Neurosci Res 77 (2):192-204.

Nishimura, F., M. Yoshikawa, S. Kanda, M. Nonaka, H. Yokota, A. Shiroi, H. Nakase, H. Hirabayashi, Y. Ouji, J. Birumachi, S. Ishizaka, and T. Sakaki. 2003. Potential use of embryonic stem cells for the treatment of mouse parkinsonian models: improved 
behavior by transplantation of in vitro differentiated dopaminergic neurons from embryonic stem cells. Stem Cells 21 (2):171-80.

Okita, K., H. Hong, K. Takahashi, and S. Yamanaka. 2010. Generation of mouse-induced pluripotent stem cells with plasmid vectors. Nat Protoc 5 (3):418-28.

Okita, K., T. Ichisaka, and S. Yamanaka. 2007. Generation of germline-competent induced pluripotent stem cells. Nature 448 (7151):313-7.

Okita, K., M. Nakagawa, H. Hyenjong, T. Ichisaka, and S. Yamanaka. 2008. Generation of mouse induced pluripotent stem cells without viral vectors. Science 322 (5903):94953.

Olanow, C. W., C. G. Goetz, J. H. Kordower, A. J. Stoessl, V. Sossi, M. F. Brin, K. M. Shannon, G. M. Nauert, D. P. Perl, J. Godbold, and T. B. Freeman. 2003. A doubleblind controlled trial of bilateral fetal nigral transplantation in Parkinson's disease. Ann Neurol 54 (3):403-14.

Olanow, C. W., O. Rascol, R. Hauser, P. D. Feigin, J. Jankovic, A. Lang, W. Langston, E. Melamed, W. Poewe, F. Stocchi, E. Tolosa, and Adagio Study Investigators. 2009. A double-blind, delayed-start trial of rasagiline in Parkinson's disease. $N$ Engl J Med 361 (13):1268-78.

Ostenfeld, T., E. Joly, Y. T. Tai, A. Peters, M. Caldwell, E. Jauniaux, and C. N. Svendsen. 2002. Regional specification of rodent and human neurospheres. Brain Res Dev Brain Res 134 (1-2):43-55.

Pahwa, R., S. A. Factor, K. E. Lyons, W. G. Ondo, G. Gronseth, H. Bronte-Stewart, M. Hallett, J. Miyasaki, J. Stevens, W. J. Weiner, and Neurology Quality Standards Subcommittee of the American Academy of. 2006. Practice Parameter: treatment of Parkinson disease with motor fluctuations and dyskinesia (an evidence-based review): report of the Quality Standards Subcommittee of the American Academy of Neurology. Neurology 66 (7):983-95.

Palmer, T. D., E. A. Markakis, A. R. Willhoite, F. Safar, and F. H. Gage. 1999. Fibroblast growth factor-2 activates a latent neurogenic program in neural stem cells from diverse regions of the adult CNS. J Neurosci 19 (19):8487-97.

Palmer, T. D., J. Ray, and F. H. Gage. 1995. FGF-2-responsive neuronal progenitors reside in proliferative and quiescent regions of the adult rodent brain. Mol Cell Neurosci 6 (5):474-86.

Papanikolaou, T., J. B. Lennington, A. Betz, C. Figueiredo, J. D. Salamone, and J. C. Conover. 2008. In vitro generation of dopaminergic neurons from adult subventricular zone neural progenitor cells. Stem Cells Dev 17 (1):157-72.

Park, C. H., J. S. Kang, Y. H. Shin, M. Y. Chang, S. Chung, H. C. Koh, M. H. Zhu, S. B. Oh, Y. S. Lee, G. Panagiotakos, V. Tabar, L. Studer, and S. H. Lee. 2006. Acquisition of in vitro and in vivo functionality of Nurr1-induced dopamine neurons. FASEB J 20 (14):2553-5.

Park, C. H., Y. K. Minn, J. Y. Lee, D. H. Choi, M. Y. Chang, J. W. Shim, J. Y. Ko, H. C. Koh, M. J. Kang, J. S. Kang, D. J. Rhie, Y. S. Lee, H. Son, S. Y. Moon, K. S. Kim, and S. H. Lee. 2005. In vitro and in vivo analyses of human embryonic stem cell-derived dopamine neurons. J Neurochem 92 (5):1265-76.

Park, I. H., N. Arora, H. Huo, N. Maherali, T. Ahfeldt, A. Shimamura, M. W. Lensch, C. Cowan, K. Hochedlinger, and G. Q. Daley. 2008. Disease-specific induced pluripotent stem cells. Cell 134 (5):877-86. 
Park, K. W., M. A. Eglitis, and M. M. Mouradian. 2001. Protection of nigral neurons by GDNF-engineered marrow cell transplantation. Neurosci Res 40 (4):315-23.

Park, S. R., R. O. Oreffo, and J. T. Triffitt. 1999. Interconversion potential of cloned human marrow adipocytes in vitro. Bone 24 (6):549-54.

Paul, G., N. S. Christophersen, H. Raymon, C. Kiaer, R. Smith, and P. Brundin. 2007. Tyrosine hydroxylase expression is unstable in a human immortalized mesencephalic cell line--studies in vitro and after intracerebral grafting in vivo. Mol Cell Neurosci 34 (3):390-9.

Perlow, M. J., W. J. Freed, B. J. Hoffer, A. Seiger, L. Olson, and R. J. Wyatt. 1979. Brain grafts reduce motor abnormalities produced by destruction of nigrostriatal dopamine system. Science 204 (4393):643-7.

Perrier, A. L., V. Tabar, T. Barberi, M. E. Rubio, J. Bruses, N. Topf, N. L. Harrison, and L. Studer. 2004. Derivation of midbrain dopamine neurons from human embryonic stem cells. Proc Natl Acad Sci U S A 101 (34):12543-8.

Peschanski, M., G. Defer, J. P. N'Guyen, F. Ricolfi, J. C. Monfort, P. Remy, C. Geny, Y. Samson, P. Hantraye, R. Jeny, and et al. 1994. Bilateral motor improvement and alteration of L-dopa effect in two patients with Parkinson's disease following intrastriatal transplantation of foetal ventral mesencephalon. Brain 117 ( Pt 3):48799.

Pittenger, M. F., A. M. Mackay, S. C. Beck, R. K. Jaiswal, R. Douglas, J. D. Mosca, M. A. Moorman, D. W. Simonetti, S. Craig, and D. R. Marshak. 1999. Multilineage potential of adult human mesenchymal stem cells. Science 284 (5411):143-7.

Reyes, M., T. Lund, T. Lenvik, D. Aguiar, L. Koodie, and C. M. Verfaillie. 2001. Purification and ex vivo expansion of postnatal human marrow mesodermal progenitor cells. Blood 98 (9):2615-25.

Reynolds, B. A., and S. Weiss. 1992. Generation of neurons and astrocytes from isolated cells of the adult mammalian central nervous system. Science 255 (5052):1707-10.

Riaz, S. S., S. Theofilopoulos, E. Jauniaux, G. M. Stern, and H. F. Bradford. 2004. The differentiation potential of human foetal neuronal progenitor cells in vitro. Brain Res Dev Brain Res 153 (1):39-51.

Richardson, R. M., W. C. Broaddus, K. L. Holloway, and H. L. Fillmore. 2005. Grafts of adult subependymal zone neuronal progenitor cells rescue hemiparkinsonian behavioral decline. Brain Res 1032 (1-2):11-22.

Rodriguez-Gomez, J. A., J. Q. Lu, I. Velasco, S. Rivera, S. S. Zoghbi, J. S. Liow, J. L. Musachio, F. T. Chin, H. Toyama, J. Seidel, M. V. Green, P. K. Thanos, M. Ichise, V. W. Pike, R. B. Innis, and R. D. McKay. 2007. Persistent dopamine functions of neurons derived from embryonic stem cells in a rodent model of Parkinson disease. Stem Cells 25 (4):918-28.

Roy, N. S., C. Cleren, S. K. Singh, L. Yang, M. F. Beal, and S. A. Goldman. 2006. Functional engraftment of human ES cell-derived dopaminergic neurons enriched by coculture with telomerase-immortalized midbrain astrocytes. Nat Med 12 (11):1259-68.

Roybon, L., T. Hjalt, N. S. Christophersen, J. Y. Li, and P. Brundin. 2008. Effects on differentiation of embryonic ventral midbrain progenitors by Lmx1a, Msx1, Ngn2, and Pitx3. J Neurosci 28 (14):3644-56.

Sagot, Y., S. A. Tan, J. P. Hammang, P. Aebischer, and A. C. Kato. 1996. GDNF slows loss of motoneurons but not axonal degeneration or premature death of $\mathrm{pmn} / \mathrm{pmn}$ mice. $J$ Neurosci 16 (7):2335-41. 
Sanchez-Ramos, J., S. Song, F. Cardozo-Pelaez, C. Hazzi, T. Stedeford, A. Willing, T. B. Freeman, S. Saporta, W. Janssen, N. Patel, D. R. Cooper, and P. R. Sanberg. 2000. Adult bone marrow stromal cells differentiate into neural cells in vitro. Exp Neurol 164 (2):247-56.

Sayles, M., M. Jain, and R. A. Barker. 2004. The cellular repair of the brain in Parkinson's disease--past, present and future. Transpl Immunol 12 (3-4):321-42.

Schumacher, J. M., S. A. Ellias, E. P. Palmer, H. S. Kott, J. Dinsmore, P. K. Dempsey, A. J. Fischman, C. Thomas, R. G. Feldman, S. Kassissieh, R. Raineri, C. Manhart, D. Penney, J. S. Fink, and O. Isacson. 2000. Transplantation of embryonic porcine mesencephalic tissue in patients with PD. Neurology 54 (5):1042-50.

Schwarz, S. C., J. Wittlinger, R. Schober, A. Storch, and J. Schwarz. 2006. Transplantation of human neural precursor cells in the 6-OHDA lesioned rats: effect of immunosuppression with cyclosporine A. Parkinsonism Relat Disord 12 (5):302-8.

Shim, J. W., H. C. Koh, M. Y. Chang, E. Roh, C. Y. Choi, Y. J. Oh, H. Son, Y. S. Lee, L. Studer, and S. H. Lee. 2004. Enhanced in vitro midbrain dopamine neuron differentiation, dopaminergic function, neurite outgrowth, and 1-methyl-4-phenylpyridium resistance in mouse embryonic stem cells overexpressing Bcl-XL. J Neurosci 24 (4):843-52.

Shinoda, M., J. L. Hudson, I. Stromberg, B. J. Hoffer, J. W. Moorhead, and L. Olson. 1995. Allogeneic grafts of fetal dopamine neurons: immunological reactions following active and adoptive immunizations. Brain Res 680 (1-2):180-95.

Shinoda, M., J. L. Hudson, I. Stromberg, B. J. Hoffer, J. W. Moorhead, L. Olson.1996. Microglial cell responses to fetal ventral mesencephalic tissue grafting and to active and adoptive immunizations. Exp Neurol 141 (2):173-80.

Soldner, F., D. Hockemeyer, C. Beard, Q. Gao, G. W. Bell, E. G. Cook, G. Hargus, A. Blak, O. Cooper, M. Mitalipova, O. Isacson, and R. Jaenisch. 2009. Parkinson's disease patient-derived induced pluripotent stem cells free of viral reprogramming factors. Cell 136 (5):964-77.

Song, T., G. Chen, Y. Wang, G. Mao, and H. Bai. 2008. Chemically defined sequential culture media for $\mathrm{TH}+$ cell derivation from human embryonic stem cells. Mol Hum Reprod 14 (11):619-25.

Sonntag, K. C., R. Simantov, K. S. Kim, and O. Isacson. 2004. Temporally induced Nurr1 can induce a non-neuronal dopaminergic cell type in embryonic stem cell differentiation. Eur J Neurosci 19 (5):1141-52.

Stadtfeld, M., M. Nagaya, J. Utikal, G. Weir, and K. Hochedlinger. 2008. Induced pluripotent stem cells generated without viral integration. Science 322 (5903):945-9.

Storch, A., G. Paul, M. Csete, B. O. Boehm, P. M. Carvey, A. Kupsch, and J. Schwarz. 2001. Long-term proliferation and dopaminergic differentiation of human mesencephalic neural precursor cells. Exp Neurol 170 (2):317-25.

Stromberg, I., M. Bygdeman, M. Goldstein, A. Seiger, and L. Olson. 1986. Human fetal substantia nigra grafted to the dopamine-denervated striatum of immunosuppressed rats: evidence for functional reinnervation. Neurosci Lett 71 (3):271-6.

Studer, L., M. Csete, S. H. Lee, N. Kabbani, J. Walikonis, B. Wold, and R. McKay. 2000. Enhanced proliferation, survival, and dopaminergic differentiation of CNS precursors in lowered oxygen. J Neurosci 20 (19):7377-83. 
Studer, L., V. Tabar, and R. D. McKay. 1998. Transplantation of expanded mesencephalic precursors leads to recovery in parkinsonian rats. Nat Neurosci 1 (4):290-5.

Svendsen, C. N., M. A. Caldwell, J. Shen, M. G. ter Borg, A. E. Rosser, P. Tyers, S. Karmiol, and S. B. Dunnett. 1997. Long-term survival of human central nervous system progenitor cells transplanted into a rat model of Parkinson's disease. Exp Neurol 148 (1):135-46.

Swistowski, A., J. Peng, Q. Liu, P. Mali, M. S. Rao, L. Cheng, and X. Zeng. 2010. Efficient generation of functional dopaminergic neurons from human induced pluripotent stem cells under defined conditions. Stem Cells 28 (10):1893-904.

Takahashi, K., K. Tanabe, M. Ohnuki, M. Narita, T. Ichisaka, K. Tomoda, and S. Yamanaka. 2007. Induction of pluripotent stem cells from adult human fibroblasts by defined factors. Cell 131 (5):861-72.

Takahashi, K., and S. Yamanaka. 2006. Induction of pluripotent stem cells from mouse embryonic and adult fibroblast cultures by defined factors. Cell 126 (4):663-76.

Tatard, V. M., G. D'Ippolito, S. Diabira, A. Valeyev, J. Hackman, M. McCarthy, T. Bouckenooghe, P. Menei, C. N. Montero-Menei, and P. C. Schiller. 2007. Neurotrophin-directed differentiation of human adult marrow stromal cells to dopaminergic-like neurons. Bone 40 (2):360-73.

Terada, N., T. Hamazaki, M. Oka, M. Hoki, D. M. Mastalerz, Y. Nakano, E. M. Meyer, L. Morel, B. E. Petersen, and E. W. Scott. 2002. Bone marrow cells adopt the phenotype of other cells by spontaneous cell fusion. Nature 416 (6880):542-5.

Tropepe, V., B. L. Coles, B. J. Chiasson, D. J. Horsford, A. J. Elia, R. R. McInnes, and D. van der Kooy. 2000. Retinal stem cells in the adult mammalian eye. Science 287 (5460):2032-6.

Trzaska, K. A., C. C. King, K. Y. Li, E. V. Kuzhikandathil, M. C. Nowycky, J. H. Ye, and P. Rameshwar. 2009. Brain-derived neurotrophic factor facilitates maturation of mesenchymal stem cell-derived dopamine progenitors to functional neurons. $J$ Neurochem 110 (3):1058-69.

Trzaska, K. A., E. V. Kuzhikandathil, and P. Rameshwar. 2007. Specification of a dopaminergic phenotype from adult human mesenchymal stem cells. Stem Cells 25 (11):2797-808.

Tseng, J. L., E. E. Baetge, A. D. Zurn, and P. Aebischer. 1997. GDNF reduces drug-induced rotational behavior after medial forebrain bundle transection by a mechanism not involving striatal dopamine. J Neurosci 17 (1):325-33.

Vierbuchen, T., A. Ostermeier, Z. P. Pang, Y. Kokubu, T. C. Sudhof, and M. Wernig. 2010. Direct conversion of fibroblasts to functional neurons by defined factors. Nature 463 (7284):1035-41.

Wagner, J., P. Akerud, D. S. Castro, P. C. Holm, J. M. Canals, E. Y. Snyder, T. Perlmann, and E. Arenas. 1999. Induction of a midbrain dopaminergic phenotype in Nurr1overexpressing neural stem cells by type 1 astrocytes. Nat Biotechnol 17 (7):653-9.

Wang, X., Y. Lu, H. Zhang, K. Wang, Q. He, Y. Wang, X. Liu, and L. Li. 2004. Distinct efficacy of pre-differentiated versus intact fetal mesencephalon-derived human neural progenitor cells in alleviating rat model of Parkinson's disease. Int J Dev Neurosci 22 (4):175-83.

Weiss, S., C. Dunne, J. Hewson, C. Wohl, M. Wheatley, A. C. Peterson, and B. A. Reynolds. 1996. Multipotent CNS stem cells are present in the adult mammalian spinal cord and ventricular neuroaxis. J Neurosci 16 (23):7599-609. 
Wernig, M., J. P. Zhao, J. Pruszak, E. Hedlund, D. Fu, F. Soldner, V. Broccoli, M. Constantine-Paton, O. Isacson, and R. Jaenisch. 2008. Neurons derived from reprogrammed fibroblasts functionally integrate into the fetal brain and improve symptoms of rats with Parkinson's disease. Proc Natl Acad Sci U S A 105 (15):585661.

Wijeyekoon, R., and R. A. Barker. 2009. Cell replacement therapy for Parkinson's disease. Biochim Biophys Acta 1792 (7):688-702.

Wilmut, I., A. E. Schnieke, J. McWhir, A. J. Kind, and K. H. Campbell. 1997. Viable offspring derived from fetal and adult mammalian cells. Nature 385 (6619):810-3.

Winkler, C., D. Kirik, and A. Bjorklund. 2005. Cell transplantation in Parkinson's disease: how can we make it work? Trends Neurosci 28 (2):86-92.

Woltjen, K., I. P. Michael, P. Mohseni, R. Desai, M. Mileikovsky, R. Hamalainen, R. Cowling, W. Wang, P. Liu, M. Gertsenstein, K. Kaji, H. K. Sung, and A. Nagy. 2009. piggyBac transposition reprograms fibroblasts to induced pluripotent stem cells. Nature 458 (7239):766-70.

Woodbury, D., E. J. Schwarz, D. J. Prockop, and I. B. Black. 2000. Adult rat and human bone marrow stromal cells differentiate into neurons. J Neurosci Res 61 (4):364-70.

Yang, D., Z. J. Zhang, M. Oldenburg, M. Ayala, and S. C. Zhang. 2008. Human embryonic stem cell-derived dopaminergic neurons reverse functional deficit in parkinsonian rats. Stem Cells 26 (1):55-63.

Yang, M., A. E. Donaldson, C. E. Marshall, J. Shen, and L. Iacovitti. 2004. Studies on the differentiation of dopaminergic traits in human neural progenitor cells in vitro and in vivo. Cell Transplant 13 (5):535-47.

Yu, J., K. Hu, K. Smuga-Otto, S. Tian, R. Stewart, Slukvin, II, and J. A. Thomson. 2009. Human induced pluripotent stem cells free of vector and transgene sequences. Science 324 (5928):797-801.

Yu, J., M. A. Vodyanik, K. Smuga-Otto, J. Antosiewicz-Bourget, J. L. Frane, S. Tian, J. Nie, G. A. Jonsdottir, V. Ruotti, R. Stewart, Slukvin, II, and J. A. Thomson. 2007. Induced pluripotent stem cell lines derived from human somatic cells. Science 318 (5858):1917-20.

Zeng, X., J. Cai, J. Chen, Y. Luo, Z. B. You, E. Fotter, Y. Wang, B. Harvey, T. Miura, C. Backman, G. J. Chen, M. S. Rao, and W. J. Freed. 2004. Dopaminergic differentiation of human embryonic stem cells. Stem Cells 22 (6):925-40.

Zhang, S. C., M. Wernig, I. D. Duncan, O. Brustle, and J. A. Thomson. 2001. In vitro differentiation of transplantable neural precursors from human embryonic stem cells. Nat Biotechnol 19 (12):1129-33.

Zhao, M., S. Momma, K. Delfani, M. Carlen, R. M. Cassidy, C. B. Johansson, H. Brismar, O. Shupliakov, J. Frisen, and A. M. Janson. 2003. Evidence for neurogenesis in the adult mammalian substantia nigra. Proc Natl Acad Sci U S A 100 (13):7925-30.

Zhou, H., S. Wu, J. Y. Joo, S. Zhu, D. W. Han, T. Lin, S. Trauger, G. Bien, S. Yao, Y. Zhu, G. Siuzdak, H. R. Scholer, L. Duan, and S. Ding. 2009. Generation of induced pluripotent stem cells using recombinant proteins. Cell Stem Cell 4 (5):381-4.

Zhou, W., and C. R. Freed. 2009. Adenoviral gene delivery can reprogram human fibroblasts to induced pluripotent stem cells. Stem Cells 27 (11):2667-74. 


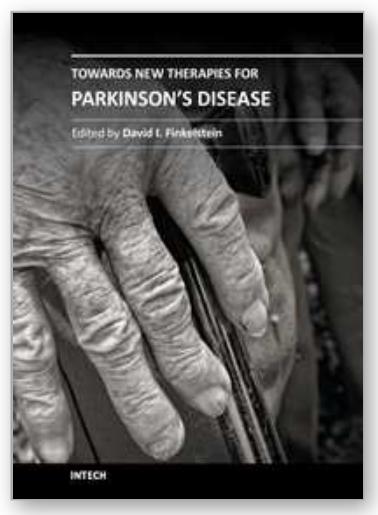

\section{Towards New Therapies for Parkinson's Disease}

Edited by Prof. David Finkelstein

ISBN 978-953-307-463-4

Hard cover, 396 pages

Publisher InTech

Published online 02, November, 2011

Published in print edition November, 2011

Parkinson's disease (PD) is characterised clinically by various non-motor and progressive motor symptoms, pathologically by loss of dopamine producing cells and intraneuronal cytoplasmic inclusions composed primarily of ?-synuclein. By the time a patient first presents with symptoms of Parkinson's disease at the clinic, a significant proportion of the cells in the substantia nigra have already been destroyed. This degeneration progresses despite the current therapies until the cell loss is so great that the quality of normal life is compromised. The dopamine precursor levodopa is the most valuable drug currently available for the treatment of PD. However for most PD patients, the optimal clinical benefit from levodopa decreases around five to six years of treatment. The aim of the chapters of this book is to work towards an understanding in the mechanisms of degeneration and to develop disease modifying therapies.

\section{How to reference}

In order to correctly reference this scholarly work, feel free to copy and paste the following:

Pia Jensen, Christina Krabbe and Morten Meyer (2011). Cell Therapy for Parkinson's Disease: Status and Perspectives, Towards New Therapies for Parkinson's Disease, Prof. David Finkelstein (Ed.), ISBN: 978-953307-463-4, InTech, Available from: http://www.intechopen.com/books/towards-new-therapies-for-parkinson-sdisease/cell-therapy-for-parkinson-s-disease-status-and-perspectives

\section{INTECH}

open science | open minds

\author{
InTech Europe \\ University Campus STeP Ri \\ Slavka Krautzeka 83/A \\ 51000 Rijeka, Croatia \\ Phone: +385 (51) 770447 \\ Fax: +385 (51) 686166 \\ www.intechopen.com
}

\author{
InTech China \\ Unit 405, Office Block, Hotel Equatorial Shanghai \\ No.65, Yan An Road (West), Shanghai, 200040, China \\ 中国上海市延安西路65号上海国际贵都大饭店办公楼 405 单元 \\ Phone: +86-21-62489820 \\ Fax: +86-21-62489821
}


(C) 2011 The Author(s). Licensee IntechOpen. This is an open access article distributed under the terms of the Creative Commons Attribution 3.0 License, which permits unrestricted use, distribution, and reproduction in any medium, provided the original work is properly cited. 